\title{
Don't it make my blue eyes brown: heterochromia and other abnormalities of the iris
}

\begin{abstract}
Eye colour is one of the most important characteristics in determining facial appearance. In this paper I shall discuss the anatomy and genetics of normal eye colour, together with a wide and diverse range of conditions that may produce an alteration in normal iris pigmentation or form.

Eye (2012) 26, 29-50; doi:10.1038/eye.2011.228;

published online 7 October 2011
\end{abstract}

Keywords: eye colour; heterochromia; neoplasm; iris; melanoma; melanocyte

\section{Introduction}

Normal eye colour and pigmentation of the iris

The anatomy of iris pigmentation. Anatomically the iris is composed of two layers of different embryological origin. The anterior layer is the iris stroma, which is derived from the mesoderm and consists of a loose collagenous network, which contains the sphincter pupillae muscle, blood vessels, nerves, and cellular elements, including fibroblasts, melanocytes, clump cells, and mast cells. The anterior border layer is a condensation of connective tissue of the anterior stroma and contains numerous pigment cells. Iris stromal, ciliary body, and choroidal melanocytes are all derived from the neural crest, a transient population of cells, unique to vertebrates. ${ }^{1,2}$ Uveal melanocytes differ from their cutaneous counterparts in one important respect: cutaneous melanocytes 'inoculate' melanosomes into the surrounding epithelial cells; by contrast, uveal melanocytes remain continent and do not release melanosomes into the surrounding tissues. The posterior pigment epithelium forms the posterior layer and is neuroectodermal in origin. The posterior pigment epithelium is
IG Rennie

derived from the anterior portion of the optic cup. It consists of two layers of cuboidal pigment cells, which are tightly joined to each other by numerous intercellular junctions. ${ }^{1,2}$

It is believed that there are four main factors, which determine iris colour: the pigment granules within the posterior pigment epithelium, the concentration of pigment within the iris stromal melanocytes, the nature of melanin pigment within the iris melanocytes, and the light-scattering and absorption properties of the extracellular stromal matrix..$^{3,4}$ It is generally considered that the concentration of melanosomes in the posterior pigment epithelium is relatively constant in normal individuals and as a result it has little impact differences in normal eye colour. The posterior pigment epithelium is only an important determinant of eye colour when it is deficient in normal melanosomes in conditions such as albinism.

The density of the iris stroma is the main determinant of colour in blue irides. The blue appearance is a result of backscatter of incident light by stromal collagen fibres. Light of longer wavelength readily penetrates the iris and is absorbed, whereas light with a shorter wavelength is reflected back and scattered by the stromal matrix. ${ }^{2,3}$ The pigment content of the iris stroma and anterior border layer is responsible for determining all of the shades of iris colour from green to dark brown. Increasing pigment within the iris stroma leads to greater light absorption and the resulting darker eye colour. ${ }^{3}$ While increasing stromal pigment content undoubtedly influences iris colour, some controversy still remains as to whether this is due to an increased number of pigment cells, the density of pigment within the cells (melanosome density in size), or the type of melanin contained within the melanosome.
Academic Unit of Ophthalmology \& Orthoptics, University of Sheffield, Sheffield, UK

Correspondence: IG Rennie, Academic Unit of Ophthalmology \& Orthoptics, University of Sheffield, Floor K, Royal Hallamshire Hospital, Glossop Road, Sheffield S10 2JF, UK Tel: + 44 (0)114 271 2902; Fax: + 44 (0)1298 872941

E-mail: i.g.rennie@ sheffield.ac.uk

Received: 19 July 2011 Accepted: 19 July 2011 Published online: 7 October 2011

Presented at the Oxford Ophthalmological Congress 2010. 
Although studies by Fuchs ${ }^{5}$ and Dietrich ${ }^{6}$ supported the notion that the number of melanocytes in the anterior border layer accounted for the differences in iris colour, other studies have concluded that the number of melanocytes within the anterior border layer are relatively constant, irrespective of eye colour. ${ }^{7}$ Further studies using electron microscopy and immunohistochemistry to examine the morphology and quantity of stromal melanocytes have again concluded that the relative numbers of these cells is not a major determinant to iris colour. ${ }^{3,8,9}$ It would appear based on the electron microscopy of the iris stroma that the number and size of melanosomes contained within melanocytes may have a significant role in determining eye colour. ${ }^{8,9}$

Melanin is an inert biopolymer that exists in two distinct forms: brown-black eumelanin and red-yellow pheomelanin. Melanocytes have the capacity to produce both forms of melanin; however, the ratio of the two forms can vary widely in individuals, producing different shades of hair and skin colour. ${ }^{10}$ In a recent study Prota et $a l^{4}$ characterised the type of melanin, which occurred in human irides. They concluded that the melanocytes within the posterior pigment epithelium contained essentially eumelanin, whereas those extracted from iris tissue in which the pigment epithelium had been removed by scraping (consisting of mainly stroma and anterior iris pigment epithelium (IPE)) contained both eumelanin and pheomelanin. Furthermore, they noted that pheomelaninic-type pigmentation was associated with green irides, whereas green blue mixed colour irides contained mostly eumelanin. By contrast, they were unable to categorise green-brown or brown irides into either of the two forms and concluded that they probably contained mixed pigment content.

The final adult iris colour is not present at birth, and in Caucasians the neonatal iris is blue as a result of a paucity of stromal melanocytes, which, presumably, have yet to migrate from the neural crest or differentiate from the primitive precursor cells. In non-White races the iris appears slate grey at birth. The iris normally adopts its true adult colour by the age of 3-5 months. ${ }^{1}$

The genetics of eye colour. In the first decade of the 20th century two reports appeared in the literature, which supported the notion that eye colour was inherited as a simple Mendelian trait. ${ }^{11,12}$ Brown eye colour was inherited as a dominant trait and blue eye colour as a recessive one, and, as a result, two blue-eyed parents were incapable of producing children with brown eyes. Although this doctrine was widely taught, it soon became apparent that occasionally blue-eyed parents could produce brown-eyed offspring and that eye colour was not inherited as a simple Mendelian trait. ${ }^{13}$ Indeed, recent studies suggest that eye colour is inherited as a polygenic trait, which, as yet, is incompletely understood.

A number of pigment genes have been implicated in determining eye colour: these include OCA2, TYRP1, MAPT, and MYO5A. ${ }^{10}$ Of these, the OCA2 gene, which is located in the long arm of chromosome-15 (15q11.2-15q-12) would appear to be the most influential. ${ }^{14}$ Mutation of OCA2 is the underlying cause of oculocutaneous albinism type-II. Moreover, deletion of the region encompassing this gene on chromosome-15 has been associated with the hypo-pigmentation of hair, skin, and eyes found in the Angelman and Prader-Willi syndromes. ${ }^{15}$ Duffy et al ${ }^{15}$ have recently reported that a Three-Single-Nucleotide polymorphism haplotype in intron-1 of the OCA2 gene can explain most of the variation in human eye colour.

\section{Congenital anomalies and abnormalities of iris pigmentation}

Binocular and sectorial heterochromia. Although, as we shall see later, both binocular and sectorial heterochromia are frequently associated with pathological conditions affecting the iris, they may, on occasion, arise as an isolated congenital abnormality. ${ }^{16}$ Sectorial

heterochromia (heterochromia iridis) arises when areas of the same iris are different in colour. This condition may be unilateral or bilateral. Several reports in the early literature suggests that this condition may arise as an autosomal dominant trait. ${ }^{16}$ It remains uncertain as to whether any of these early reports were in fact describing patients with Waardenburg syndrome. Moreover, sectorial heterochromia may be confused with an extensive iris naevus. Recently, bilateral sectorial iris heterochromia has been described in a case of chromosome $13 q$ deletion syndrome. ${ }^{17}$

Binocular heterochromia (heterochromia iridum) has been recognised, in both humans and animals, from the very early times and was referred to as 'heteroglaucos' by Aristotle. ${ }^{16}$ The Byzantine Emperor Anastasius I was called Dicorous because, according to chroniclers, his right eye was 'glauci' (bluish green or bluish grey) and the left eye black. Both eyes were apparently normal in all other respects. Anastasius I was over 90 years old when he died and this would suggest that he was not suffering from any systemic disease or syndrome, which would have normally foreshortened his lifespan. ${ }^{18}$ According to Plutarch, Alexander the Great also suffered from heterochromia iridum. ${ }^{16}$ Binocular heterochromia may arise as an isolated congenital anomaly or as an autosomal dominant trait. ${ }^{16}$ Heterochromia iridum has also been reported in association with Sturge-Weber syndrome, ${ }^{19}$ hypomelanosis of Ito ${ }^{20}$ and linear 
scleroderma. ${ }^{21}$ Recently, Quinlan and Shwayder ${ }^{22}$ reported a case of a large facial café au lait macule in association with heterochromia iridum. The macule was extensive and involved both the upper and the lower eyelids. The patient had one blue and one brown iris. Interestingly, the blue iris was on the same side as the café au lait macule. Heterochromia has also been described in association with iris colobomas. In a study of 75 children in Scotland with iris colobomas, 13 (17.3\%) of these patients were noted to be suffering from iris heterochromia. In cases where the coloboma was unilateral, the affected iris was always darker in colour. ${ }^{23}$

Congenital Horner's syndrome. In 1893 Angelucci noted a de-pigmentation of the uveal tract of dogs and rabbits, which had been subjected to surgical excision of the superior cervical ganglion, ${ }^{16}$ and in 1904 Abelsdorff ${ }^{24}$ noted heterochromia in cats following similar procedures. Subsequently, Calhoun in $1919^{25}$ reported a series of experiments on rabbits and rodents in which he noted that hypo-pigmentation of the iris was related to the length of survival after sympathectomy. Clinically, the association of congenital Horner's syndrome and iris de-pigmentation, producing heterochromia, is wellrecognised. Weinstein et $a l^{26}$ found iris heterochromia in 9 of 11 patients with congenital Horner's syndrome and in all cases the site of the lesion was considered to be due to disruption of the postganglionic neurone. In one of the remaining patients, both irides were very light blue, making the diagnosis of heterochromia impossible. The final patient did not suffer from heterochromia and was considered to have an interruption of the pre-ganglionic pathway. They considered that disruption of the postganglionic pathway could lead to a neurotropic dysgenesis of iris melanocytes. ${ }^{26}$ In a further study of 23 children presenting with Horner's syndrome in the first year of life, $78 \%$ were found to have iris heterochromia. ${ }^{27}$

Although less common, it would appear that cases of acquired Horner's syndrome in childhood and adult life may occasionally also give rise to iris heterochromia. Laties $^{28}$ reported a case of a 29-year-old female who had developed Horner's syndrome, with associated heterochromia, following the removal of a neurolemmoma when aged 14. Diesenhouse et al ${ }^{29}$ subsequently reported two cases of Horner's syndrome following sympathectomy, which were associated with the development of iris hypo-pigmentation. A number of reports in the literature have also indicated the development of iris heterochromia in children who develop Horner's syndrome as a result of either a cervical ganglioneuroma, ${ }^{30}$ neurolemmoma, ${ }^{31}$ or neuroblastoma. ${ }^{32,33}$ Again, it is interesting to note that in all cases of heterochromia-associated acquired Horner's syndrome, the causal lesion was postganglionic in origin.
The development of iris hypo-pigmentation following disruption to the postganglionic sympathetic fibres to the eye clearly suggests that adrenergic innervation is important in the maintenance of iris pigmentation. Laties $^{28}$ in a study of the effect of sympathectomy in rabbits, noted a rapid reduction in tyrosinase activity in both the iris and the choroid following interruption to the sympathetic innervation of the eye. Furthermore, Mukuno and Witmer ${ }^{34}$ in an electron microscopic study of the human iris, identified contacts between melanocytes and nerve terminals in the stroma. They described four distinct types of nerve terminals apparently making synaptic contact with melanocytes and concluded that at least two of these were adrenergic in origin. Adrenergic innervation of melanocytes has also been reported in the iris of monkeys and rabbits. ${ }^{35}$ McCartney et $a^{36}$ undertook an electron microscopic study of an iris in a case of congenital Horner's syndrome. They noted a significant reduction in melanocytes in both the anterior border and stromal layers when compared with the unaffected iris. The number of melanosomes in the residual melanocytes did not appear to be reduced. The authors concluded that the reduction in melanocytes in the anterior border and stromal layers may have been due to failure of migration of neural crest-derived melanocytes in the early postnatal period. Iris hypo-pigmentation in cases of Horner's syndrome in adult life could be due to an attrition of the normal monocyte population following sympathetic denervation. ${ }^{36}$ Interestingly, three naevi were present on the surface of the affected iris and these showed no signs of pigment loss: a finding also noted by Dryja and Albert $^{37}$ in a clinical study of an affected iris. These findings suggest that naevus cells do not share the same sympathetic innervation as stromal melanocytes.

Waardenburg syndrome. In 1947 Waardenburg, a Dutch ophthalmologist and geneticist, described a deaf mute man with medial canthal dystopia, blepharophimosis, and partial iris atrophy to a meeting of the Dutch Ophthalmological Society. ${ }^{38}$ He noted similarities in this case and those previously described in a pair of monozygotic twin girls. ${ }^{39}$ Waardenburg subsequently undertook a systematic search among 1050 inmates of five Dutch institutions for the deaf; he found 12 individuals with clinical manifestations of the disease. ${ }^{38,40}$ The results of this study were published in a seminal paper in the American Journal of Human Genetics in $1951^{41}$ and define the syndrome now known as Waardenburg syndrome type-I, which had six main features: lateral displacement of the medial canthi combined with dystopia of the lacrimal punctum and blepharophimosis; prominent broad nasal root; hypertrichosis of the medial part of the eyebrows, white 
forelock, heterochromia iridis; and deaf-mutism. ${ }^{40,41}$ There are now four recognised variants of Waardenburg syndrome (types I-IV) all of which are inherited by an autosomal dominant trait, with the exception of Waardenburg syndrome type-IV, which appears to have a mostly autosomal recessive mode of inheritance. ${ }^{38}$ Mutations of the PAX3 gene have been implicated in Waardenburg syndrome types I and III, whereas approximately $15 \%$ of type-II have mutations of the MITF gene. ${ }^{40}$ Mutations of the endothelin-3 (EDN3), endothelin receptor-B (EDNRB), and SOX10 genes have been found in patients with Waardenburg syndrome type-IV. ${ }^{40,42}$ PAX3, MITF, and SOX10 are transcription factors and EDNRB and EDN3 are signalling molecules, all of which appear to have a role in the development of melanocytes from primitive neural crest cells. ${ }^{43,44}$

Three types of pigmentary disturbance of the iris have been observed in Waardenburg syndrome and include complete heterochromia iridis, partial, or segmental heterochromia (Figure 1a), which maybe unilateral or bilateral, and bilateral isohypochromia iridis (pale blue eyes). ${ }^{38,40}$ Iris heterochromia, either partial or complete, is found in between 21 and $28 \%$ of individuals with Waardenburg syndrome ${ }^{40}$ and appears to be most common in the type-II variant, with a reported frequency of $47 \% .{ }^{45}$ Isohypochromia iridis has a reported incidence of $14.9-42 \%{ }^{40}$

Histopathological studies of the irides of patients with Waardenburg syndrome are limited. Mullaney et al ${ }^{46}$ described the light and electron microscopic findings of the irides in a patient with the type-II variant of Waardenburg syndrome. They found a reduction in the number of stromal melanocytes in deep blue iris when compared with the fellow brown eye. Furthermore, the melanosomes were smaller and fewer in number in the blue iris when compared with the brown iris. ${ }^{46}$

Iris freckles. Iris freckles are flat, discrete areas of brown pigmentation on the iris surface. They do not distort the architecture of the iris stroma: an important clinical sign
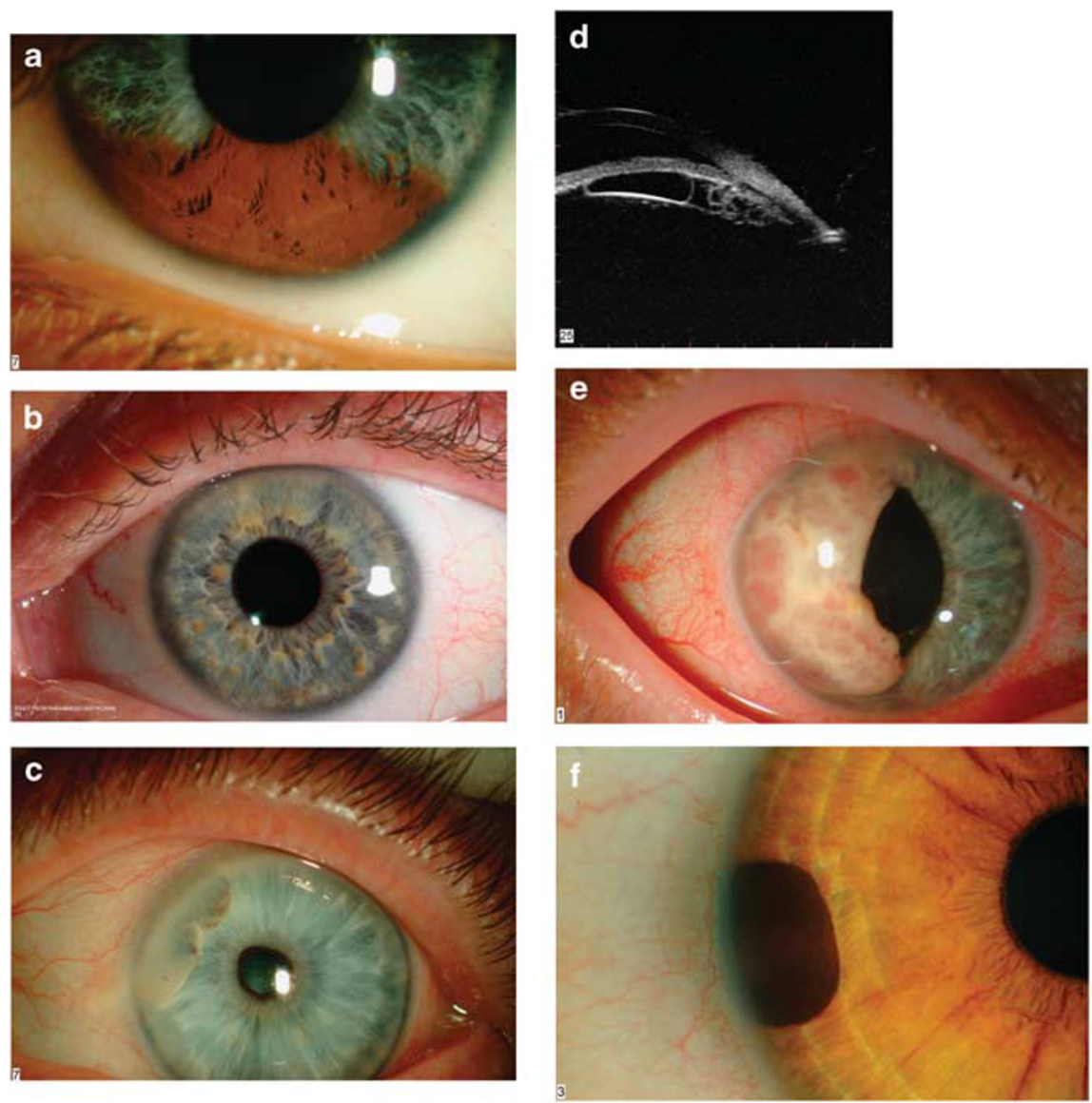

Figure 1 (a) Sectorial pigmentation in Waardenburg syndrome. (b) Lisch nodules in neurofibromatosis type-I. Note the predominant inferior location. (c) Anterior stromal cyst containing a turbid sediment. (d) Multiple posterior pigment epithelial cysts. This patient presented with raised intraocular pressure. Note the plateaux iris configuration. (e) A large iris metastasis in a patient with an occult bronchiogenic carcinoma. (f) A peripheral iris melanocytoma. 
when differentiating them from naevi and other melanocytic tumours of the iris. Iris freckles are extremely common and may be found in over $60 \%$ of the general population. ${ }^{47}$ There is no evidence to suggest that iris freckles are capable of malignant transformation.

Lisch nodules. In 1937 Karl Lisch ${ }^{48}$ reported his observations of brown nodules on the surface of the iris in three patients with neurofibromatosis and as a result such lesions now bear his name. However, as is the case with many medical eponymous terms, Lisch was not first to describe the presence of pigmented iris nodules in neurofibromatosis. Snell and Treacher Collins, ${ }^{49}$ Goldstein and Wexler, ${ }^{50}$ Fuchs, $^{51}$ and Sakurai ${ }^{52}$ all describe similar patients prior to Lisch. Moreover, Van der Hoeve ${ }^{53}$ in his 1932 Doyne Memorial lecture on the eye symptoms in phakomatoses described a family with neurofibromatosis and iris lesions originally observed by Waardenburg. Although not pathognomonic, Lisch nodules rarely occur in patients not suffering from neurofibromatosis type-I. Lal et $a l^{54}$ reported a case of unilateral Lisch nodules in a 14 -year-old boy who otherwise had no other signs of NF1. They commented that this could represent a somatic mutation of the NF1 with limited mosaicism, perhaps limited to only that sector of the iris. Lisch nodules have also been described in Cushing's disease, ${ }^{55}$ familial angiolipomatosis, ${ }^{56}$ and neurofibromatosis type-II. ${ }^{57}$

Lisch nodules are not present at birth and usually appear in the late childhood, after the appearance of café au lait spots but before the development of overt neurofibromas. ${ }^{58}$ Almost all patients with NF1 older than 20 years of age will have Lisch nodules. ${ }^{59}$ Clinically, Lisch nodules are small ( $>1 \mathrm{~mm}$ diameter) discrete yellow or brown, dome-shaped nodules on the surface of the iris. They usually have a smooth surface with a gelatinous like interior. While the finding of two or more Lisch nodules is one of the diagnostic criteria for NF1, most affected irides contain many more and occasionally in excess of a hundred are found to be present in the adult eye. ${ }^{58}$

Early histopathological studies suggested that Lisch nodules were melanocytic hamartomas. In 1982 Perry and Font described the electron microscopic appearances of Lisch nodules in an iridectomy specimen obtained from a 75-year-old male suffering from NF1. They found that the nodules were composed of spindle-shaped cells, which were melanocytic in origin, and based on these observations they suggested that they were indeed melanocytic hamartomas. ${ }^{60}$ Williamson $e t$ al ${ }^{61}$ in a further electron microscopic study also suggested that Lisch nodules were melanocytic in origin. However, more recent observations have cast doubt on the hamartomatous nature of these lesions and suggest that they should be considered as benign iris tumours. Richetta et $a l^{62}$ studied the histopathological and ultrastructural features of a Lisch nodule obtained from a 50-year-old woman with NF1 and found that it was composed of three main cell types: pigmented cells, fibroblast-like cells, and mast cells. They concluded that Lisch nodules were histologically similar to neurofibromas. Clinical studies have also challenged the concept that Lisch nodules are true hamartomas. Nichols et $a l^{63}$ in a study of 369 patients with NF1 noted that in $80 \%$ of affected eyes the Lisch nodules were located inferiorly. Wood et al ${ }^{64}$ reported a single case of inferiorly located Lisch nodules in a patient suffering from bilateral ptosis. In a recent study Boley et $a l^{65}$ mapped and quantified the distribution of Lisch nodules in 73 adults with NF1 and found that the number of nodules in the inferior hemifield was statistically greater when compared with the superior hemifield (Figure 1b). They also noted that the light irides harboured significantly more Lisch nodules than the dark irides. These findings suggest that Lisch nodules may arise secondary to exposure to UV light from sunlight for it is thought that the lower half of the iris receives a greater amount of incident sunlight than the upper hemifield. ${ }^{66,67}$ Indeed, as we shall see later, iris melanomas are also usually located in the inferior hemifield. If UV exposure is a factor in the development of Lisch nodules, then this presumably is due to DNA damage, which would suggest that these lesions are benign tumours rather than true hamartomas. Although elements of this argument are persuasive, it does not explain why these lesions are homogeneous in appearance, fail to continue to grow throughout life, and apparently do not undergo occasional malignant transformation as would be expected with other benign tumours.

Ocular/oculodermal melanocytosis. In 1861 Hulke ${ }^{68}$ reported a case of a uveal malignant melanoma arising in a female patient who was noted to have pigmentation of the eyelid, eyebrow sclera, and fundus. A number of sporadic cases involving pigmentation of the peri-ocular skin, sclera, and conjunctiva subsequently appeared in the literature ${ }^{69}$ before, in 1938, Ota $^{70}$ at a meeting of the dermatological society in Japan, described the condition, which now bears his name. The following year Tanino ${ }^{71}$, Ota's pupil, published a report of 26 cases of Naevus of Ota. Fitzpatrick et $a l^{72}$ first proposed the term oculodermal melanocytosis for Naevus of Ota and ocular melanocytosis for pigmentation of the ocular tissues in the absence of an associated peri-ocular naevus. It is now apparent that these conditions represent a spectrum of congenital pigmentation involving the skin and/or ocular tissues. In a study by Teekhasaenee et $a l^{73}$ of 194 affected patients, they found that $67(34.5 \%)$ had skin 
involvement alone, 12 (6.2\%) had only ocular involvement, and the remaining 115 (59.3\%) had both ocular and dermal pigmentation.

Histologically, the cutaneous elements of oculodermal melanocytosis contain spindle and dendritic cells in the dermis resembling melanocytes migrating from the neural crest to the epidermis. ${ }^{74}$ In this respect oculodermal melanocytosis is similar to Mongolian spot, naevus of Ito, and blue naevus. Histopathological studies of affected eyes have shown the presence of pigmented stellate melanocytes distributed throughout the sclera and episcleral tissues together with increased numbers of benign plump dendritic monocytes within the choroid. ${ }^{75-77}$ An ultrastructural study of an affected iris demonstrated the presence of numerous melanocytes in the anterior border and iris stromal layers. Many of these melanocytes, in addition to a normal-sized melanosomes, contained large round macromelanosomes, which probably reflects a basic defect in melanogenesis within the cells. ${ }^{77}$

Naevus of Ota together with naevus of Ito and Mongolian spot have been classified as hamartomatous congenital dermal melanocytoses involving the migration of neural crest-derived melanocytes during embryogenesis. ${ }^{74}$ Indeed, it has been suggested that Naevus of Ota arises as a result of an arrest in the migration of neural crest melanocytes, which leads to the aggregation of these cells in the dermis. ${ }^{78}$ While this hypothesis provides a plausible explanation for the presence of melanocytes within the affected dermis, it does not explain the excessive numbers of melanocytes found within the ocular tissues. Other explanations include local changes in the embryonic environment, which leads to the preferential differentiation of migrating neural crest cells into a melanocytic phenotype. ${ }^{79}$ Whatever the precise explanation, there can be little doubt that ocular and oculodermal melanocytosis arise as a result of a perturbation of migrating neuro crest melanocytes.

Oculodermal melanocytosis is apparent at or soon after birth; in over $50 \%$ of cases it is almost always manifest by the end of the second decade of life. ${ }^{73,80}$ Ocular melanocytosis (Naevus of Ota) is more common in Orientals than in Caucasian or Black individuals. Studies in Japan have reported a prevalence ranging from 0.4 to $0.84 \% .^{81}$ In a study to determine the prevalence rate of ocular and oculodermal melanocytosis Gonder $e a^{81}$ found the prevalence of ocular melanocytosis in White individuals to be $0.038 \%$ and oculodermal melanocytosis in the Black population to be $0.014 \%$. Oculodermal melanocytosis is generally considered to occur more frequently in females. Hidano et $a l^{80}$ reported that oculodermal melanocytosis occurred five times more frequently in women than in men.
However, other investigators have suggested that this apparent predilection for females may be distorted by the fact that women may be more likely to present to dermatology clinics as a result of their cosmetic appearance than males. ${ }^{73}$ Oculodermal melanocytosis is usually a unilateral, although sporadic cases of bilateral involvement have been reported in the literature. ${ }^{82-88}$ The vast majority of cases of ocular or oculodermal melanocytosis are sporadic in nature and only rarely have familial cases been reported in the literature. ${ }^{89-92}$

Clinically, oculodermal melanocytosis is characterised by a bluish-grey pigmentation ${ }^{88}$ involving areas of skin innervated by the first and the second divisions of the trigeminal nerve. Occasionally, there may be pigmentation of the eardrum, buccal mucosa, palate, nasopharynx, and leptomeninges. ${ }^{78,93}$ A number of ocular tissues may be involved, including the conjunctiva, episclera, cornea, iris, lens, anterior chamber angle, choroid, and optic disc. ${ }^{73}$ The episclera is almost always involved and may range from relatively discreet bluish spots to confluent dark mottled patches, which are dispersed randomly on the globe, but usually do not involve the limbus. ${ }^{73}$ Episcleral blood vessels crossing the involved areas are frequently separated from the pigmentation by a narrow, non-pigmented band. Hyperpigmentation of the choroid producing a dark fundus when compared with the fellow eye is found in approximately $80 \%$ of cases. ${ }^{73}$ Iris involvement, which may be generalised or sectorial, is present in almost $90 \%$ of cases. The degree of iris involvement is variable and ranges from the presence of stellate granules on an otherwise normal iris to a dense uniform pigmentation, which obscures the underlying iris architecture. ${ }^{73}$ Iris mammillations, which appear as regularly spaced, deep brown, smooth, conical elevations that cover the iris surface giving it a velvety appearance to the naked eye, are found in cases of ocular and oculodermal melanocytosis. ${ }^{94}$ These changes may be the initial manifestation of ocular melanocytosis in the absence of conjunctival or episcleral pigmentation. ${ }^{95}$ Iris mammillations are not exclusive to ocular melanocytosis and have been observed sporadically or in association with systemic conditions, including phakomatosis pigmentovascularis type-IIb and neurofibromatosis type-I. ${ }^{94}$ Rarely, iris mammillations may be familial. ${ }^{96}$

Ocular and oculodermal melanocytosis have been reported in association with a number of ocular conditions, including; glaucoma, ${ }^{73,97-103}$ retinitis pigmentosa, ${ }^{104}$ congenital cataract, ${ }^{105}$ and Duane's syndrome. ${ }^{106}$ However, there can be little doubt that the most important association is the development of uveal melanoma in the eyes involved by these conditions. There have been numerous reports in the literature since the first description by Hulke ${ }^{68}$ of the development of 
uveal melanomas in cases of ocular and oculodermal melanocytosis..$^{75,76,86,95,107-135}$ Singh et al ${ }^{136}$ estimated the lifetime risk of a patient with ocular or oculodermal melanocytosis of developing a uveal melanoma to be approximately 1 in 400 as compared with 1 in 13000 for the general population. This represents an approximately 30 -fold increased risk. Ninety percent of the patients who developed a melanoma did so between the ages of 31 and 80 years. There have been relatively few reports of iris melanomas developing in the context of ocular or oculodermal melanocytosis, which probably reflects a relative rarity of these tumours when compared with posterior uveal melanomas. ${ }^{113,132,134,135}$

\section{Iris cysts}

Primary iris stromal cysts. Primary iris stromal cysts are rare, with the majority of reports in the literature limited to single case studies. ${ }^{137-181}$ Clinically, primary iris stromal cysts appear as dome-shaped translucent masses arising from the mid or peripheral surface of the iris. They may appear lobulated and usually contain a clear or slightly turbid fluid, although occasionally they may contain a sediment of white or yellowish material resembling a hypopyon within the cyst ${ }^{155,171}$ (Figure 1c). The majority of cases are diagnosed within the first year of life, with occasional cases reported in adults. ${ }^{155}$ This condition appears to be unilateral in that the author is unaware of any reports of bilateral involvement. In most cases a stromal cyst arises in the inferior or temporal aspect of the iris. ${ }^{155}$ In general, primary iris stromal cysts, particularly in children, undergo progressive enlargement, which may lead to visual loss when they encroach upon the visual axis. ${ }^{155}$ Rarely, spontaneous collapse or regression of a stromal cyst has been reported. ${ }^{156,176,177}$ Focal corneal oedema may arise as a result of contact between the stromal cyst and the corneal endothelium. ${ }^{137,142,161,163}$ Raised intraocular pressure, ${ }^{159,163,172,173}$ hyphaema ${ }^{137}$ iritis, and subluxation of the lens ${ }^{163,167,171,173-175}$ have been found in association with primary iris stromal cysts.

Although primary iris stromal cysts may develop in adults, they are generally considered to be congenital in origin. Stromal cysts, which arise later in life, have probably been dormant and become apparent as the result of an accumulation of fluid within the cyst, triggered by an unknown stimulus. ${ }^{170}$ The precise aetiology of primary iris stromal cysts remains unclear and proposed mechanisms include developmental entrapment of surface ectoderm, neuroectoderm, or surface ectodermal implantation as a result of occult trauma. ${ }^{163}$ Histologically, primary iris stromal cysts are lined with a multi-layered squamous or cuboidal epithelium, which may or may not contain mucin-secreting goblet cells. ${ }^{138,139,142,163,168-170,173,174,178,179}$ Occasionally, focal keratinisation of the epithelial lining has been observed. ${ }^{170,180}$ Immunohistochemical studies have demonstrated a positive reaction for epithelial cytokeratin markers and a negative result for the S100 antigen. ${ }^{159,163,166,170}$ Electron microscopic studies have shown the presence of microvilli on the luminal surface of the epithelial cells together with desmosomes and tonofilaments. ${ }^{163,166,170,178}$ These studies support the notion that primary iris stromal cysts originate from the surface ectoderm, displaced probably at the time of formation of the lens vesicle. ${ }^{170}$ Rummelt et al ${ }^{182}$ reported two cases of congenital epithelial iris cysts in children who had a maternal history of diagnostic amniocentesis. In one case a perforating limbal scar with a corresponding break in a Descemet's membrane was observed. Lois et al ${ }^{155}$ in a series of 17 patients with primary iris stromal cysts noted a history of diagnostic amniocentesis in two patients. However, in neither case was there any sign of a penetrating injury to the eye. It would appear that while diagnostic amniocentesis is a possible cause of congenital stromal iris cysts, the majority of cases occur in the absence of any obvious intrauterine trauma.

A wide range of modalities have been used to treat symptomatic primary iris stromal cysts, including simple aspiration, ${ }^{155,171}$ and injection with trichloroacetic acid, ${ }^{158}$ xenon photocoagulation, ${ }^{158}$ neodymium-YAG laser, ${ }^{164,171}$ argon laser photocoagulation, ${ }^{155,181}$ cryotherapy, ${ }^{155,181}$ iridectomy, ${ }^{158,142}$ and block excision. ${ }^{160,180}$ Unfortunately, re-occurrence following treatment, particularly simple puncture either surgical or laser, is common and prognosis for vision, particularly in young children where amblyopia may be a problem, is often poor. Recently, Shen et $a l^{144}$ reported a promising surgical technique by using a viscoelastic material to dissect the cyst from the corneal endothelium, followed by aspiration of the cyst, excision, and micro-diathermy.

Posterior cysts. Primary cysts of the IPE or ciliary body have been recognised for over a century. ${ }^{183}$ In 1897 Zimmerman ${ }^{183}$ reported a case of bilateral pigmented tumours, which he considered to be ciliary body cysts. Following this report, a number of case reports appeared in the literature noting the appearance of cysts of either the ciliary body or IPE. ${ }^{184-187}$ Although initially considered as separate entities, it would now appear that the majority of cysts of the IPE and ciliary body arise from the irido-ciliary sulcus or pars plicata, and should best be considered as irido-ciliary cysts (vide infra).

Historically, irido-ciliary cysts were considered to be rare; however, with the advent of the ultrasound biomicroscope it is now recognised that small asymptomatic cysts are extremely common and that only 
a small proportion of them attain sufficient size or number to become clinically apparent. Recently, Kunimatsu et $a l^{188}$ in a prospective study of 232 eyes of 116 normal subjects by using an ultrasound biomicroscope found evidence of irido-ciliary cysts in $54.3 \%$ of patients.

In 1981 Shields ${ }^{140}$ reported a study of 62 patients with primary iris cysts, of which 59 were considered to have arisen from the posterior pigment epithelium. He classified the pigment epithelial cysts into five groups: central, mid-zonal, peripheral, dislodged into the anterior chamber, and dislodged into the posterior chamber. In a subsequent study using the same classification, Lois et $a l^{189}$ reported the clinical features and the natural course of primary cysts of the IPE in 234 patients. They found central (confined to the pupillary margin) in three patients $(6 \%)$, mid-zonal cysts in 50 patients $(21 \%)$, peripheral in 170 patients $(73 \%)$, and dislodged in eight patients (3\%). However, less than $10 \%$ of these patients underwent an ultrasound biomicroscope examination to confirm the extent and the posterior origin of the cysts. Subsequent studies using ultrasound biomicroscope would suggest that both peripheral and mid-zonal cysts originate from the iridociliary sulcus. ${ }^{190,191}$ Indeed, in the author's personal experience, all large cysts involving the mid-zone appear to arise from the irido-ciliary sulcus. It is probable that the majority, if not all, of pigment epithelial cysts (with the exception of those that have become detached and now float in either the vitreous or aqueous) arise either from the pupil margin or the irido-ciliary sulcus. Moreover, as we shall see, the aetiology of these two groups appears to be quite distinct.

Although the majority of small peripheral pigment epithelial (irido-ciliary) cysts are asymptomatic, large cysts can cause focal abnormalities of the iris, which may, on occasion, stimulate an ocular neoplasm. Sadly, prior to the advent of the ultrasound biomicroscope, pigment epithelial cysts had been mistaken for ciliary body melanomas resulting in unnecessary enucleation. ${ }^{186}$ Clinically, isolated peripheral irido-ciliary cysts present as a focal anterior bulging of the peripheral iris, with an associated shallowing of the anterior chamber. Larger cysts may be visible at the pupil margin, particularly following pharmacological mydriasis. In these circumstances the cyst appears as a smooth uniformly pigmented mass lying between the posterior surface of the iris and the lens. On careful inspection the cyst will usually transilluminate when a fine slit-lamp beam is shone upon its surface. The majority of solitary pigment epithelial cysts appear to arise in the inferior temporal quadrant. ${ }^{189}$ Bilateral pigment epithelial cysts are common and indeed, when an individual presents with an apparently unilateral lesion, careful inspection of the fellow eye will frequently reveal the presence of an occult lesion in that eye. Occasionally, patients may present with multiple bilateral irido-ciliary cysts ${ }^{191}$ (Figure 1d) and in extreme cases this may produce a plateau iris leading to angle closure glaucoma. ${ }^{189,191-199}$ Although irido-ciliary cysts are generally sporadic in nature, Vela et $a l^{197}$ reported three families with pigment epithelial cysts, which were multiple in 10 and bilateral in eight of the 11 affected patients. Acute closed angle glaucoma occurred in four of the affected patients.

Although the aetiology of irido-ciliary cysts remains uncertain, numerous theories have been proposed, including; persistence of the annular sinus of von Szily; ${ }^{198}$ foetal iritis causing synechiae with resultant separation of the two layers of the secondary optic vesicle; ${ }^{200}$ and embryonic traction of the zonule of Zinn on the posterior epithelial layer of the secondary optic cup. ${ }^{186}$ It is tempting to speculate that, given peripheral pigment epithelial cysts appear to arise from the iridociliary sulcus where there is transition between the nonpigmented epithelium of the ciliary body and the pigment epithelium of the iris, their formation may be due to a focal juxtaposition of these elements, leading to the aberrant secretion of aqueous beneath the pigment epithelium.

While the majority of peripheral pigment epithelial cysts occur in isolation, it is well-recognised that on occasion they may be associated with a ciliary body tumour. Augsburger et $a l^{201}$ noted, in a study by using the ultrasound biomicroscope, that in 39 patients with pigment epithelial cysts, six occurred at the margin of a ciliary body tumour. Fine and Pavlin ${ }^{190}$ in a further ultrasound biomicroscopic study of 210 irido-ciliary cysts found that $20 \%$ were associated with a tumour. While the majority of these cysts are clinically undetectable and can only be diagnosed with the aid of an ultrasound biomicroscope, occasionally iris cysts may be the presenting sign of a ciliary body tumour ${ }^{202}$ and for this reason it is important to exclude an associated neoplasm in any patient who presents with an apparently isolated pigment epithelial cyst. Moreover, cystic ciliary body melanomas may simulate a pigment epithelial cyst and again this phenomena reinforces the need to undertake a meticulous ultrasound biomicroscope examination in any patient presenting with a solitary cyst. ${ }^{203}$

Central pigment epithelial cysts, arising from the pupillary margin, are a well-recognised product of miotic therapy. In $1923 \operatorname{Vogt}^{204}$ described single or multiple cysts at the pupillary margin in patients receiving miotic (pilocarpine) therapy for chronic simple glaucoma. Abraham $^{205}$ in a study of 66 cases of accommodative strabismus treated with di-isopropyl-fluoro-phosphate noted that pupillary cysts developed in 42 (64\%) patients and that occasionally they occur as early as 2 weeks after 
starting treatment. Chin $e t a^{206}$ reported the occurrence of pupillary cysts in patients receiving phospholine iodide for accommodative strabismus; they noted that this effect could be inhibited by concomitant therapy with the mydriatric phenylephrine. Histologically, the cysts are found to contain finger-like projections consisting of a double layer of pigment epithelial cells enclosing cystic spaces. ${ }^{207}$

In 1936 Cowan $^{208}$ described a case of familial cysts and flocculi of the iris. Flocculi have been described as tuft-like excrescences of the pigment epithelium overlying the pupil margin and are often cystic in nature. It is probable that they are aetiologically closely related to simple pigment epithelial cysts and indeed in some articles the term appears interchangeable. More recently, Sallo and Hatvani ${ }^{209}$ reported four cases of primary pupillary pigment epithelial cysts in a single family. Although there was no mention of any systemic abnormality in this pedigree, several articles have suggested an association between iris flocculi/pupillary pigment cysts and inherited ascending thoracic aortic aneurysms and dissections (TAAD). ${ }^{210-214}$ In the past few years several research groups have identified that TAAD may be caused by mutations of the smooth muscle $\alpha$-actin (ACTA2) ${ }^{213,214}$ gene and moreover, that iris flocculi may be specific to the p.R149C mutation.

\section{Vascular tumours and malformations of the iris}

Vascular tumours and malformations of the iris are extremely rare. Ashton ${ }^{215}$ in a pathological study of 145 primary iris tumours found only three primary angiomas of the iris. Indeed, Ferry ${ }^{216}$ in an archival study concluded that the majority of tumours classified as haemangiomas were in fact juvenile xanthogranulomas, highly vascular melanomas or other non-vascular tumours. However, true vascular tumours and malformations of the iris have been reported in the literature and include capillary, ${ }^{217-220}$ cavernous, $^{221-226}$ racemose,$^{227-231}$ microhaemangiomas, ${ }^{232-239}$ and iris varix. $^{240-243}$

Capillary haemangiomas are paediatric malformations and appear to arise in association with either diffuse neonatal haemangiomatosis or peri-orbital capillary haemangiomas. ${ }^{217-220}$ In general, cavernous

haemangiomas arise in adulthood and are not associated with systemic haemangiomas. ${ }^{222,241}$ However, sporadic case reports have detailed their association with haemangiomas in other non-ocular sites. ${ }^{241}$

Microhaemangiomas (iris vascular tufts) are probably the most common vascular malformation to arise in the iris, with a total of approximately 90 reported cases in the literature. ${ }^{234}$ They typically occur bilaterally and appear as solitary or multiple small (approximately $150 \mu \mathrm{m}$ in diameter) vascular tufts on the pupil margin. Most cases occur in patients over 50 years of age and indeed, iris microhaemangiomas have not been reported in childhood. ${ }^{234}$ Although microhaemangiomas have been reported in association with a wide variety of systemic conditions, these are probably, in the majority of cases, merely coincidental, with the possible exceptions of myotonic dystrophy ${ }^{244-246}$ and diabetes mellitus. ${ }^{232,246}$ Spontaneous hyphaema, which may be complicated by secondary raised intraocular pressure, is a well-recognised complication of iris vascular tufts. ${ }^{23,239,247-256}$ Iris microhaemangiomas are thought to be hamartomas arising from the stromal blood vessels. ${ }^{235}$

In 1983 Stur and Strasser ${ }^{227}$ described a sectorial racemose arterio-venous malformation in a 32-year-old male. Since this report approximately 36 further cases of isolated iris arterial-venous malformation have been reported in the literature. ${ }^{230,241}$ These lesions consist of one or more abnormally large iris blood vessels that originate in the iridocorneal angle, which pass through the stroma (which in places may obscure them) towards the pupil margin for a variable distance before forming an abrupt loop and returning to the angle. ${ }^{229}$ Fluorescein angiography readily identifies these vascular malformations, which fill rapidly and demonstrate no or only minimal leakage or staining of the vessel wall. ${ }^{229} \mathrm{~A}$ dilated episcleral vessel in the same quadrant as the arterio-venous malformation was noted in $50 \%$ of cases. ${ }^{229}$ The presence of such a vessel may be confused with sentinel vessels, which are associated with an underlying ciliary body tumour. Iris arterio-venous malformations are not associated with any systemic condition, nor do they give rise to any symptoms.

\section{Iris tumours}

Adenomas and adenocarcinomas of the IPE. Adenomas and adenocarcinomas of the IPE are rare. Spraul et al, ${ }^{257}$ in 1996, reported an adenocarcinoma of the IPE and cited 20 previously reported cases, which would appear to fulfil the criteria to be classified as adenomas of the IPE. Shields et $\mathrm{l}^{258}$ in 1999 reported their personal experience of 20 cases of adenomas arising from the IPE. Since then, only a further single report of an adenoma of the IPE has appeared in the literature. ${ }^{259}$ The majority of adenomas of the IPE appear to arise from the peripheral iris and may involve the ciliary body. Moreover, adenomas may arise from the pigment epithelium of the ciliary body and, as a result, it is often difficult on clinical grounds to determine which pigment epithelium the tumour has arisen from. Clinically, adenomas of the IPE present as a small asymptomatic mass in the peripheral iris. There appears to be no sex or racial predilection, and typically such lesions present in the fourth to sixth decade of life. 
Rarely, adenomas may present in childhood and adolescence. We have reported a case of an adenoma, which was composed of pigmented and non-pigmented elements, involving both the iris and the ciliary body, which was probably congenital in origin. ${ }^{260}$ In most cases adenomas appear as a sharply defined black or dark grey lesion, which has displaced the iris root. The exposed surface of the lesion may be smooth or nodular, and, unlike ciliary body melanomas, there are no associated sentinel vessels. Despite their relatively small size, adenomas of the iris (and ciliary) epithelium frequently erode the iris root giving the appearance of anterior segment invasion. In general, invasion of the iris is a feature of large ciliary body melanomas and thus the finding of a small 'ciliary body' tumour in the presence of apparent invasion of the iris root should alert the clinician to the possibility that the lesion is a benign adenoma. ${ }^{261}$ Adenomas of the IPE appear as homogenous or, occasionally, cystic lesions with a smooth or nodular surface arising from the posterior aspect of the iris. Histologically, adenomas of the IPE appear as deeply pigmented tumours composed of cords and tubules of well-differentiated pigment epithelial cells separated by connective tissue septae. Occasional cystic spaces may be visible within the tumour. ${ }^{258}$ To the author's knowledge there have been only two reported cases of adenocarcinomas arising from the IPE. ${ }^{257,262}$ However, although the histological features were suggestive of a malignant neoplasm, there have been no reported cases of metastases from these tumours, in keeping with adenocarcinomas of the ciliary and retinal pigment. ${ }^{257}$ Adenomas of the IPE may be treated by surgical resection or observation. ${ }^{258}$

Iris metastasis. In contrast with the choroid, which is a relatively common site for metastases, ${ }^{263,264}$ the iris is rarely involved in the metastatic process. Bloch and Gartner, $^{264}$ in study of 230 eyes obtained post mortem from patients with confirmed systemic malignancy, found 28 cases of ocular metastases, of which only two (7\%) involved the iris. The majority of published cases are confined to single case reports. To date, the largest study in the literature was published by Shields et $a l^{265}$ who in a study of 512 patients with uveal metastases, found iris involvement in $40(7.8 \%)$ of cases. The breast $(40 \%)$ and lung $(28 \%)$ were the most common location for the primary tumour. In approximately one-third of cases, the iris metastasis was the presenting symptom of the underlying malignancy (Figure 1e). In this series 35\% of cases had an accompanying choroidal metastasis. The iris metastases were unilateral in all cases. Again, this contrasts with the choroid where bilateral involvement occurs in approximately $30 \%$ of cases. Indeed, bilateral iris involvement appears to be extremely uncommon. ${ }^{266-268}$
Iris metastases typically appear as a solitary yellowwhite or pink fleshy mass on the iris stromal surface. The tumours often appear friable and may liberate cells into the anterior chamber, which can simulate anterior uveitis. ${ }^{265,269}$ In addition, iris metastases are capable of invoking a significant inflammatory reaction and as a result may present with a true anterior uveitis. ${ }^{269-273}$ Secondary glaucoma is frequently associated with iris metastases occurring in approximately $40 \%$ of cases. ${ }^{265}$ The diagnosis of an iris metastasis may be relatively straightforward when a patient presents with known carcinomatosis, particularly when there is an associated choroidal deposit. However, when the patient presents with a solitary iris lesion in the absence of a history of malignant disease, the diagnosis may be more problematic. In these circumstances a fine-needle aspiration, or punch biopsy, may be of value. ${ }^{265,274-277}$

\section{Melanocytic tumours of the iris stroma}

Naevi. Although iris naevi are undoubtedly common, precise estimates of their prevalence within the general population are lacking. In part, this is due to the fact that the majority of patients with iris naevi are asymptomatic and, as a result, do not seek medical attention.

Furthermore, as we shall see, the clinical, and indeed the pathological, distinction between naevi, melanocytomas, and melanomas is somewhat blurred and as a result the precise categorisation of an individual melanocytic iris lesion may be problematic. In a small study, Harbour et $a l^{47}$ found the incidence of iris naevi to be between 4 and $6 \%$. Iris naevi appear to be more common in patients with light-coloured irides ${ }^{47}$ and individuals with the dysplastic naevus syndrome. ${ }^{278,279}$

Clinically, iris naevi may be circumscribed or diffuse in nature and in both forms the lesion effaces or obscures the underlying iris stromal architecture: a feature, which differentiates them from a simple iris ephelis where the architecture is preserved. Circumscribed naevi appear as a well-demarcated lesion, which may vary in size, shape, and degree of pigmentation. The majority of naevi are tan or dark brown in colour, occur in the lower half of the iris, and may involve the pupil margin, mid-zone, or periphery. Traditionally, it has been told that pupillary changes, including corectopia, ectropion uvea, and sector lens opacities, were suggestive of malignancy. However, it is now recognised that such changes may occur in naevi and cannot be used to distinguish benign from malignant lesions. ${ }^{280,281}$ Similarly, involvement of the iridocorneal angle, which was again once thought to be indicative of malignancy, may occur in benign naevi. ${ }^{281}$

Diffuse naevi appear as flat or minimally elevated pigmented lesions, which involve a sector, or occasionally, the entire iris, and are congenital in nature. 
They are usually encountered in cases of ocular or oculodermal melanocytosis. ${ }^{133}$ A diffuse iris naevus may also be encountered in Cogan-Reese syndrome. This condition first described in $1969,{ }^{282}$ is a variant of the iridocorneal endothelial syndrome, and is characterised by unilateral glaucoma; abnormalities of the corneal endothelium; and iris changes, including, corectopia, ectropion uvea, pigmented nodules, and iris atrophy. ${ }^{283}$

Iris naevi are generally indolent lesions, which remain asymptomatic throughout life. Occasionally, secondary glaucoma may arise as a result of pigment deposition in the trabecular meshwork. Although rapid tumour growth is considered to be indicative of malignancy, iris naevi may slowly increase in size with time. In a study of 175 melanocytic tumours of the iris, Territo et $a l^{284}$ noted definite tumour growth in eight patients, of which five were treated by iridocyclectomy. Two of these lesions were subsequently found to be spindle cell naevi.

Two reports have now appeared in the literature describing an aggressive naevus of the iris in children. Paridaens et $a l^{285}$ described an apparently unique familial occurrence of an aggressive iris naevus arising in the second decade of life in a mother and son. Carlson et al ${ }^{286}$ subsequently reported an aggressive iris naevus in a 16-year-old girl who presented with visual loss as a result of uncontrolled secondary glaucoma.

While it is probable that iris naevi may occasionally undergo malignant transformation, it is not possible to estimate how frequently this change occurs. Many iris melanocytic lesions, which histologically appear to be malignant, may remain indolent for many years and as result, should a lesion show a significant increase in size, it may be impossible to determine whether this is due to malignant transformation in a pre-existing naevus of growth in a previously dormant melanoma.

Melanocytoma. A melanocytoma is a specific type of naevus, which demonstrates characteristic histological features. They are composed of deeply pigmented plump or polyhedral naevus cells, which contain abundant cytoplasm and demonstrate little nuclear pleomorphism. ${ }^{287}$ Although melanocytomas typically arise on or adjacent to the optic disc, they may occasionally occur in other locations in the eye, including the choroid, ${ }^{288-298}$ the ciliary body, ${ }^{299-312}$ and the iris. ${ }^{299,301,313-327}$

In 1965 Zimmerman $^{313}$ reported an iris melanocytoma in a 34-year-old, which was treated by iridectomy and subsequent enucleation, the initial specimen having been reported to be a malignant melanoma. Since then a number of reports have appeared in the literature documenting the occurrence of melanocytomas within the iris. ${ }^{297,299,311-325}$ These lesions are, however, uncommon, and in a study of 200 patients referred to an ocular oncology service with the suspected diagnosis of an iris melanoma, 158 were found to have an alternative diagnosis and of these only one proved to be a melanocytoma. ${ }^{328}$ In a subsequent study of 47 cases of iris melanocytoma, Demirci et al ${ }^{322}$ estimated that melanocytomas represented only $3 \%$ of all iris naevi.

Clinically, iris melanocytomas appear as a darkly pigmented nodule with an irregular or corrugated surface $^{322}$ (Figure 1f). In keeping with other melanocytic iris lesions, melanocytomas usually involve the inferior half of the iris. These lesions appear to be less cohesive than ordinary naevi and may produce satellite lesions on the iris surface or trabecular meshwork. ${ }^{287}$ This lack of cohesion may be due to necrosis within the melanocytoma. ${ }^{314,318,322,324}$ Involvement of the trabecular meshwork may give rise to a raised intraocular pressure. ${ }^{314,315,318,324}$ Indeed, Demirci et al ${ }^{322}$ in their study noted that $11 \%$ of patients had developed a raised intraocular pressure at 5 and 10 years, and that this had risen to $55 \%$ at 15 years. Approximately $50 \%$ of iris melanocytomas may demonstrate a gradual enlargement with time, ${ }^{322}$ and although this is not indicative of malignant transformation, there are sporadic reports of melanomas arising from iris melanocytomas in the literature. ${ }^{316,325,329}$

Melanoma. Iris melanomas are uncommon and account for only between 2 to $5 \%$ of all uveal melanomas. ${ }^{330,331}$ Despite their relative rarity, iris melanomas remain an enigma and controversy surrounds both their diagnosis and management. Most studies indicate that the mean age of presentation for iris melanomas is $40-45$ years: a decade earlier than their posterior uveal counterparts. ${ }^{330-332}$ Iris melanomas may be either circumscribed or diffuse, and in both forms the clinical distinction between a melanoma and benign naevus may be difficult.

Circumscribed melanomas have an affinity for the inferior iris and approximately $80 \%$ of cases arise from the inferior half of the iris. ${ }^{332}$ They appear as a raised lesion with either a smooth or irregular surface. The degree of pigmentation is variable and while the majority of iris melanomas are brown in colour, some are amelanotic: the latter often showing a prominent intrinsic vasculature. Pupil distortion, ectropion uveae, localised cataract, iridocorneal angle involvement, pigment dispersion, raised intraocular pressure, and spontaneous hyphaema may be found in iris melanomas. ${ }^{284,330}$

Diffuse iris melanomas are extremely rare, accounting for $7-10 \%$ of all iris melanomas. ${ }^{330,333}$ Clinically, diffuse iris melanomas classically present as a patient with 
unilateral hyperchromatic heterochromia and ipsilateral glaucoma. ${ }^{333-335}$ In affected cases the iris has a diffuse or multifocal pigmentation. Associated corectopia and ectropion iridis occur in approximately $90 \%$ of cases and involvement of the iridocorneal angle appears to be a universal feature. ${ }^{333}$ Unfortunately, there is frequently a significant delay in diagnosing diffuse iris melanomas. Demirci et $a l^{333}$ in a report of 25 cases of diffuse iris melanoma found that $14(56 \%)$ of the cases referred to their unit for further management had previously been diagnosed elsewhere as suffering from glaucoma and that as a result there was a mean delay of 30 months before eventual diagnosis was made. A subsequent review of the literature confirmed a similar delay in diagnosing diffuse iris melanomas. ${ }^{333}$ This is in keeping with the authors' own experience where the condition had initially been misdiagnosed as Cogan-Reese syndrome. Histologically, diffuse iris melanomas, in contrast to circumscribed tumours, frequently contain epithelioid cells, which tend to be poorly cohesive and may account for the diffuse nature of these lesions. ${ }^{333}$

In 1951 Stallard ${ }^{336}$ wrote that the prognosis for iris melanomas treated by iridectomy was good. A few years later Rones and Zimmerman ${ }^{332}$ in a retrospective study of 125 cases of iris lesions, which they considered to be either malignant or have malignant potential obtained from the Armed Forces Institute of Pathology files, found the incidence of metastases for patients with iris melanoma to be $1 \%$ at 5 years and $6 \%$ at 10 years. They observed that the iris melanomas appeared to have a different natural history than their posterior uveal counterparts. Subsequent studies have confirmed that iris melanomas generally have a very favourable prognosis and that the risk of death from metastasisrelated disease is small. ${ }^{337-343}$ The one exception to this general rule appears to be diffuse iris melanomas where the overall risk of metastases appears to be significantly greater. ${ }^{333}$

The apparently favourable prognosis for iris melanomas, together with the difficulty in clinically differentiating many lesions from naevi, has prompted many clinicians to adopt a conservative approach to the treatment of such lesions; proposing treatment should rapid growth or other significant complications occur. Traditionally, circumscribed iris melanomas have been treated by iridectomy or iridocyclectomy. ${ }^{331-345}$ Alternative treatment modalities include plaque brachytherapy $^{346,347}$ and proton beam irradiation. ${ }^{348-350}$ The management of diffuse iris melanomas is problematic and most are probably best treated by enucleation, although irradiation may be tried in cases where the patient is reluctant to suffer loss of their eye. ${ }^{333}$

The apparently low risk of metastatic disease in cases of iris melanoma contrasts with that of choroidal and ciliary body tumours where the mortality rates are significantly greater. In 1992, Diener-West et al $l^{351}$ published a meta-analysis of the 5-year mortality rates among patients who had an eye enucleated for a choroidal melanoma and found the combined weighted estimates to be $16 \%$ for small, $32 \%$ for medium, and $53 \%$ for large tumours. In a recent study of the very-long-term prognosis of patients with choroidal and ciliary body melanoma, Kujala et $a^{352}$ found tumour-related mortality to be $31 \%$ by 5 years, $45 \%$ by 15 years, $49 \%$ by 25 years, and $52 \%$ by 35 years. This, of course, poses the intriguing question as to why there should be such a disparity in relative survivals between iris and posterior uveal melanoma.

Jakobiec and Silbert ${ }^{280}$ in a retrospective clinical pathological study of 189 iris and iris and ciliary body lesions originally diagnosed as melanomas proposed a new nine part histological classification for such tumours. They subsequently reassigned $87 \%$ of the tumours studied into one of six categories, all of which they considered to be benign. ${ }^{280}$ In doing so they suggested that most iris 'melanomas' were in fact benign naevi. If this were indeed the case, then the apparently favourable prognosis for such tumours in previously reported series could be explained by the inclusion of benign lesions into the study groups, which would have the effect of diluting the true malignant neoplasms. While this may the case, it does not entirely explain this paradox. In 2001 Shields et al $^{331}$ reported the results of a study of 169 consecutive patients with microscopically confirmed iris melanoma and found a metastatic rate of $3 \%$ at 5 years and $5 \%$ at 10 years, which is remarkably similar to the results found by Rones and Zimmerman ${ }^{332}$ over 40 years earlier. However, although this excellent study provides us with the incidence of metastatic disease for patients with histologically proven iris melanoma, it suffers from an inherent flaw when considering the overall prognosis for patients with iris melanomas. In this study they obtained the incidence of metastases in 169 patients with histologically proven iris melanoma from a total cohort of 1054 patients referred to the ocular oncology service with suspicious iris melanocytic tumours. The decision to treat or obtain histological biopsy of the lesion was, of course, based on their clinical criteria for possible malignancy. It is of course conceivable that in the remaining 885 patients with the presumptive diagnosis of an iris naevus managed by observation, there may have been patients where the diagnosis would have been that of a melanoma had the tumour been removed and submitted for histological examination.

It is an established fact that tumour size at the time of diagnosis is an important factor in determining the prognosis for posterior uveal melanomas. ${ }^{351}$ In general, 
iris melanomas are significantly smaller than most choroidal or ciliary body melanomas at the time of diagnosis, and this has prompted the argument that the apparent difference in biological behaviour can merely be attributed to tumour size. Davidorf ${ }^{353}$ noted that the mean volume of iris melanomas at the time of diagnosis was $55 \mathrm{~mm}^{3}$ compared with a mean volume of $300 \mathrm{~mm}^{3}$ for choroidal melanomas and concluded that if the size of the tumour at the time of diagnosis was taken into account the metastatic rates would be comparable. Again, the same problem arises: the major criterion for intervention in the case of melanocytic lesion of the iris is documented growth and it is possible that tumours, which histologically would be considered malignant, are left untreated because of the lack of any observable change in size.

In 1990, Prescher et $a l^{354}$ reported apparently nonrandom chromosome abnormalities in 14 cases of posterior uveal melanoma. Shortly afterwards, my own group reported similar findings in six cases of uveal melanoma. ${ }^{355}$ Following these initial reports it has now been established that not only do non-random chromosome abnormalities occur in uveal melanomas, but that certain abnormalities, namely loss of chromosome- 3 and additional copies of the long arm of chromosome-8, arise predominantly in ciliary body tumours and are highly sensitive predictors of patient survival. ${ }^{356-359}$ Unfortunately, to date, there are only two studies (a total of four cases), which have characterised the cytogenetic changes in iris melanomas. ${ }^{360,361}$

However, based on this limited evidence it would appear that, although iris melanomas experience relatively high levels of chromosome alterations, they are different to those that are typically found in posterior uveal tumours. If the results of these preliminary results were confirmed in a larger cohort of patients, it could implicate differences in tumour karyotype as a possible cause for the apparent disparity between the metastatic rates of the iris and posterior uveal melanomas.

There is one further intriguing possibility that could explain the apparently different biological nature of the iris and posterior uveal melanomas: could differences in the anterior chamber micro-environment have a role in modulating the behaviour of iris melanomas? Grossniklaus et $a^{362}$ used a murine model to investigate a difference in metastatic rate between anterior and posterior ocular melanoma, and found that $33 \%$ of the tumours inoculated into the anterior chamber metastasised in comparison with $89 \%$ of those inoculated into the choroid and/or vitreous. Recently, we have investigated the possible role of the micro-environment in tumour growth. In an in vitro study of the effect of aqueous and vitreous humours on invasion and proliferation, we found that although neither appeared to influence tumour cell proliferation, vitreous promoted tumour invasion whereas aqueous either had no effect or was inhibitory. ${ }^{363}$ In a further study we identified six enucleation specimens where there was clear invasion of the tumour through the iris stroma and onto the surface. We noted that the surface melanoma cells were smaller when compared with those deeper within the lesion and that fewer of these cells expressed cyclin-D1, a protein that promotes the cell cycle. Moreover, expression of p27, a factor, which inhibits the cell cycle, had a high level of expression in these cells on the anterior tumour surface than those located within the lesion. We also investigated alterations of chromosome- 3 and 8 , and found them to be less common among the iris surface melanoma cells than those deeper within the body of the tumour. ${ }^{364}$ Although these results to date must be considered as preliminary, it is plausible that factors within the aqueous humour may have a role in modulating the growth of iris melanomas. If such factors could be identified then they may provide the basis for developing alternative therapies to treat uveal melanoma.

\section{Conflict of interest}

The authors declare no conflict of interest.

\section{Acknowledgements}

I am indebted to my colleagues who work closely in the ocular oncology service, Paul Rundle, Rhona Jacques, Lesley Hinchliffe, and Michele Evans, without whose continuing support this lecture would not have been possible. Finally, I dedicate this lecture to Sydney Davidson, my friend and mentor for the past 30 years.

\section{References}

1 Bron AJ, Tripathi RC, Tripathi BJ. Wolff's Anatomy of the Eye and Orbit. 8th edn. Chapman \& Hall Medical: London, 1997.

2 Imesch PD, Wallow IH, Albert DM. The colour of the human eye: a review of morphologic correlates and of some conditions that affect iridial pigmentation. Surv Ophthalmol 1997; 41(Suppl 2): S117-S123.

3 Wilkerson CL, Syed NA, Fisher MR, Robinson NL, Wallow $\mathrm{IH}$, Albert DM. Melanocytes and iris colour. Light microscopic findings. Arch Ophthalmol 1996; 114(4): 437-442.

4 Prota G, Hu DN, Vincensi MR, McCormick SA, Napolitano A. Characterization of melanins in human irides and cultured uveal melanocytes from eyes of different colours. Exp Eye Res 1998; 67(3): 293-299.

5 Fuchs E. Normal pigmentierte und albinotische iris. Graefes Arch Clin Exp Ophthalmol 1913; 84/85: 521.

6 Dieterich CE. [The fine structure of melanocytes in the human iris]. Graefes Arch Clin Exp Ophthalmol 1972; 183(4): 317-333.

7 Wolfrum P. Über den Bau der Irisvorderfläche des menschlichen Auges mit vergleichend anatomischen 
Bemerkungen. Graefes Arch Clin Exp Ophthalmol 1922; 109: 106-153.

8 Eagle Jr RC. Iris pigmentation and pigmented lesions: an ultra structural study. Trans Am Ophthalmol Soc 1988; 86: 581-687.

9 Imesch PD, Bindley CD, Khademian Z, Ladd B, Gangnon R, Albert DM et al. Melanocytes and iris colour. Electron microscopic findings. Arch Ophthalmol 1996; 114(4): 443-447.

10 Sturm RA, Frudakis TN. Eye colour: portals into pigmentation genes and ancestry. Trends Genet 2004; 20(8): 327-332.

11 Davenport GC, Davenport CB. Heredity of eye-colour in man. Science 1907; 26: 590-592.

12 Hurst CC. On the inheritance of eye-colour in man. Proc $R$ Soc Med Lond B Biol Sci 1908; 80: 81-86.

13 Sturm RA, Larsson M. Genetics of human iris colour and patterns. Pigment Cell Melanoma Res 2009; 22(5): 544-562.

14 Sturm RA. Molecular genetics of human pigmentation diversity. Hum Mol Genet 2009; 18: 9-17.

15 Duffy DL, Montgomery GW, Chen W, Zhao ZZ, Le L, James MR et al. A three-single-nucleotide polymorphism haplotype in intron 1 of OCA2 explains most human eyecolour variation. Am J Hum Genet 2007; 80(2): 241-252.

16 Duke Elder S. System of Ophthalmology. Henry Kimpton: London, 1964.

17 Kutzbach B, Mendelsohn N, Rath P, Summers CG. Sectora iris heterochromia and retinal pigment variation in 13qsyndrome. J Am Assoc Pediatr Ophthalmol Strabismus 2007; 11(5): 513-515.

18 Lascaratos J. 'Eyes' on the thrones: imperial ophthalmologic nicknames. Surv Ophthalmol 1999; 44(1): 73-78.

19 Sullivan TJ, Clarke MP, Morin JD. The ocular manifestations of the Sturge-Weber syndrome. J Pediatr Ophthalmol Strabismus 1992; 29(6): 349-356.

20 Pascual-Castroviejo I, Lopez-Rodriguez L, de la Cruz Medina M, Salamanca-Maesso C, Roche Herrero C. Hypomelanosis of Ito. Neurological complications in 34 cases. Can J Neurol Sci 1988; 15(2): 124-129.

21 Stone RA, Scheie HG. Periorbital scleroderma associated with heterochromia iridis. Am J Ophthalmol 1980; 90(6): 858-861.

22 Quinlan K, Shwayder T. Cafe au lait macule associated with heterochromia iridis. Pediatr Dermatol 2005; 22(2): 177-178.

23 Morrison DA, FitzPatrick DR, Fleck BW. Iris coloboma with iris heterochromia: a common association. Arch Ophthalmol 2000; 118(11): 1590-1591.

24 Abelsdorff G. Über Blauäugigkeit und Heterophthalmus bei tauben albinotischen Tieren. Graefes Arch Clin Exp Ophthalmol 1904; 59: 376-377.

25 Calhoun FP. Causes of heterochromia iridis with special reference to paralysis of the cervical sympathetics. Am J Ophthalmol 1919; 2: 255-269.

26 Weinstein JM, Zweifel TJ, Thompson S. Congenital Horner's syndrome. Arch Ophthalmol 1980; 98: 1074-1078.

27 George ND, Gonzalez G, Hoyt CS. Does Horner's syndrome in infancy require investigation? $\mathrm{Br} \mathrm{J} \mathrm{Ophthalmol}$ 1998; 82(1): 51-54.

28 Laties AM. Ocular melanin and the andrenergic innovation of the eye. Trans Am Ophthalmol Soc 1974; 72: 560-605.

29 Diesenhouse MC, Palay DA, Newman NJ, To K, Albert DM. Acquired heterochromia with horner syndrome in two adults. Ophthalmology 1992; 99(12): 1815-1817.
30 McRae Jr D, Shaw A. Ganglioneuroma, heterochromia iridis, and Horner's syndrome. J Pediatr Surg 1979; 14(5): 612-614.

31 Sayed AK, Miller BA, Lack EE, Sallan SE, Levey RH. Heterochromia iridis and Horner's syndrome due to paravertebral neurilemmoma. J Surg Oncol 1983; 22(1): $15-16$.

32 Jaffe N, Cassady R, Petersen R, Traggis D. Heterochromia and Horner syndrome associated with cervical and mediastinal neuroblastoma. J Pediatr 1975; 87(1): 75-77.

33 Riggs Jr W, Benton C, Wood B. Cervical neurogenic tumours presenting as thoracic apical masses in infants and children. Pediatr Radiol 1977; 5(4): 201-203.

34 Mukuno K, Witmer R. Innervation of melanocytes in human iris. An electron microscopic study. Graefes Arch Clin Exp Ophthalmol 1977; 203: 1-8.

35 Ringvold A. An electron microscopic study of iris stroma in monkey and rabbit with particular reference to intercellular contacts and sympathetic innervation of anterior layer ceils. Exp Eye Res 1975; 20: 349-365.

36 McCartney AC, Riordan-Eva P, Howes RC, Spalton DJ. Horner's syndrome: an electron microscopic study of a human iris. Br J Ophthalmol 1992; 76(12): 746-749.

37 Dryja TP, Albert DM. Lack of adrenergic influence on the pigmentation of iris nevus cells. Arch Ophthalmol 1980; 98(11): 1996.

38 Read AP, Newton VE. Waardenburg syndrome. J Med Genet 1997; 34(8): 656-665.

39 Van der Hoeve J. Augenanomalien bei kongenitalfamiliärer Taubheit und bei Labyrintherkrankung. Klin Monbl Augenheilkd 1913; 51: 461-470.

40 Dourmishev AL, Dourmishev LA, Schwartz RA, Janniger CK. Waardenburg syndrome. Int J Dermatol 1999; 38(9): 656-663.

41 Waardenburg PJ. A new syndrome combining developmental anomalies of the eyelids, eyebrows, and nose root with pigmentary defects of the iris and head hair and with congenital deafness. Dystopia canthi medialis et punctorum lacrimalium lateroversa, hyperplasia supercilii medialis et readicis nasi, heterochromia iridum totalis sive partialis, albinismus circumscriptus (leucismus, poliosis), et surditas congenital (surdimutitas). Am J Hum Genet 1951; 3: 195-253.

42 Inoue K, Shilo K, Boerkoel CF, Crowe C, Sawady J, Lupski $\mathrm{JR}$ et al. Congenital hypomyelinating neuropathy, central demyelination and Waardenburg-Hirschsprung disease: Phenotypes linked by SOX10 mutation. Ann Neurol 2002; 52: 836-842.

43 Hou L, Pavan WJ. Transcriptional and signaling regulation in neural crest stem cell-derived melanocyte development: do all roads lead to Mitf? Cell Res 2008; 18(12): 1163-1176.

44 Thomas AJ, Erickson CA. The making of a melanocyte: the specification of melanoblasts from the neural crest. Pigment Cell Melanoma Res 2008; 21(6): 598-610.

45 Liu XZ, Newton VE, Read AP. Waardenburg syndrome type II: phenotypic findings and diagnostic criteria. $A m \mathrm{~J}$ Med Genet 1995; 55(1): 95-100.

46 Mullaney PB, Parsons MA, Weatherhead RG, Karcioglu ZA. Clinical and morphological features of Waardenburg syndrome type II. Eye 1998; 12: 353-357.

47 Harbour JW, Brantley Jr MA, Hollingsworth H, Gordon M. Association between posterior uveal melanoma and iris freckles, iris naevi, and choroidal naevi. $\mathrm{Br} J$ Ophthalmol 2004; 88(1): 36-38. 
48 Lisch K. Ueber Beteiligung der Augen, insbesondere das Vorkommen von Irisknötchen bei der Neurofibromatose (Recklinghausen). Augenheilkunde 1937; 93: 137-143.

49 Snell S, Treacher Collins E. Plexiform neuroma (elephantiasis neuromatosis) of temporal region, orbit, eyelid and eyeball. Notes of three cases. Trans Ophthalmol Soc UK 1903; 23: 157-177.

50 Goldstein I, Wexler D. Melanosis uveae and melanoma of the iris in neurofibromatosis (Recklinghausen). Arch Ophthalmol 1930; 3: 288-296.

51 Fuchs E. Naevus pigmentosus und Naevus vasculosus der Iris. Albrecht Von Graefes Arch Klin Exp Ophthalmol 1913; 86: 155-169.

52 Sakurai K. Multiple neurofibroma patient showing multiple flecks on the anterior surface of the iris. Acta Soc Ophthalmologicae Japonicae 1935; 39: 87-89.

53 Van der Hoeve J. The Doyne Memorial Lecture. Eye symptoms in phakomatoses. Trans Ophthalmol Soc UK 1932; 52: 380-401.

54 Lal G, Leavitt JA, Lindor NM, Mahr MA. Unilateral Lisch nodules in the absence of other features of neurofibromatosis 1. Am J Ophthalmol 2003; 135(4): 567-568.

55 Bouzas EA, Mastorakos G, Chrousos GP, Kaiser-Kupfer MI. Lisch nodules in Cushing's disease. Arch Ophthalmol 1993; 111(4): 439-440.

56 Cina SJ, Radentz SS, Smialek JE. A case of familial angiolipomatosis with Lisch nodules. Arch Pathol Lab Med 1999; 123(10): 946-948.

57 Charles SJ, Moore AT, Yates JR, Ferguson-Smith MA. Lisch nodules in neurofibromatosis type 2. Case report. Arch Ophthalmol 1989; 107(11): 1571-1572.

58 Sippel KC. Ocular findings in neurofibromatosis type 1. Int Ophthalmol Clin 2001; 41(1): 25-40.

59 Ferner RE. Neurofibromatosis 1 and neurofibromatosis 2: a twenty first century perspective. Lancet Neurol 2007; 6(4): 340-351.

60 Perry HD, Font RL. Iris nodules in von Recklinghausen's Neurofibromatosis. Electron microscopic confirmation of their melanocytic origin. Arch Ophthalmol 1982; 100(10): 1635-1640.

61 Williamson TH, Garner A, Moore AT. Structure of Lisch nodules in neurofibromatosis type 1. Ophthalmic Paediatr Genet 1991; 12(1): 11-17.

62 Richetta A, Giustini S, Recupero SM, Pezza M, Carlomagno $\mathrm{V}$, Amoruso $\mathrm{G}$ et al. Lisch nodules of the iris in neurofibromatosis type 1. J Europ Acad Dermatol Venereol 2004; 18(3): 342-344.

63 Nichols JC, Amato JE, Chung SM. Characteristics of Lisch nodules in patients with neurofibromatosis type 1.J Pediatr Ophthalmol Strabismus 2003; 40(5): 293-296.

64 Wood TD, Egan RA, Portland OR. Inferior predilection of Lisch nodules with ptosis. Neurology 2005; 64(8): 1370.

65 Boley S, Sloan JL, Pemov A, Stewart DR. A quantitative assessment of the burden and distribution of Lisch nodules in adults with neurofibromatosis type 1. Invest Ophthalmol Vis Sci 2009; 50(11): 5035-5043.

66 Graziosi P, Rosmini F, Bonacini M, Ferrigno L, Sperduto $\mathrm{RD}$, Milton RC et al. Location and severity of cortical opacities in different regions of the lens in age-related cataract. Invest Ophthalmol Vis Sci 1996; 37: 1698-1703.

67 Sydenham MM, Collins MJ, Hirst LW. Measurement of ultraviolet radiation at the surface of the eye. Invest Ophthalmol Vis Sci 1997; 38: 1485-1492.

68 Hulke JW. A series of cases of carcinoma of the eyeball. Ophthalmic Hosp Rep 1860-61; 3: 279-286.
69 Mishima Y, Mevorah B. Nevus Ota and nevus Ito in American Negroes. J Invest Dermatol 1961; 36: 133-154.

70 Ota M. Nevus fusco-caeruleus ophthalmo-maxillaris. Jpn J Dermatol 1939; 46: 369.

71 Tanino H. Über eine in Japan häufig vorkommende Navusform: "Naevus fusco-caeruleus ophthalmomaxillaris Ota", I. Mitteilung: Beobachtung über Lokalisation, Verfärbung, Anordnung und histologische Veränderung. Jpn J Dermatol Urol 1939; 46: 107-111.

72 Fitzpatrick T, Zeller R, Kukita A, Kitamura H. Ocular and oculodermal melanocytosis. Arch Ophthalmol 1956; 56: 830-832.

73 Teekhasaenee C, Ritch R, Rutnin U, Leelawongs N. Ocular findings in oculodermal melanocytosis. Arch Ophthalmol 1990; 108(8): 1114-1120.

74 Zembowicz A, Mihm MC. Dermal dendritic melanocytic proliferations: an update. Histopathology 2004; 45(5): 433-451.

75 Honavar SG, Shields CL, Singh AD, Demirci H, Rutledge BK, Shields JA et al. Two discrete choroidal melanomas in an eye with ocular melanocytosis. Surv Ophthalmol 2002; 47(1): 36-41.

76 Pomeranz GA, Bunt AH, Kalina RE. Multifocal choroidal melanoma in ocular melanocytosis. Arch Ophthalmol 1981; 99(5): 857-863.

77 Rennie IG, Bleehen SS. Melanosis oculi: an ultrastructural study of an affected iris. Arch Ophthalmol 1983; 101: 1912-1916.

78 Kopf AW, Weidman AL. Nevus of Ota. Arch Dermatol 1962; 85: 195-208.

79 Benson MT, Rennie IG. Hemi-naevus of Ota: perturbation of neural crest differentiation as a likely mechanism. Graefes Arch Clin Exp Ophthalmol 1992; 230(3): 226-229.

80 Hidano A, Kajima H, Ikeda S, Miyasato H, Niimura M. Natural history of nevus of Ota. Arch Dermatol 1967; 95: 187-195.

81 Gonder JR, Ezell PC, Shields JA, Augsburger JJ. Ocular melanocytosis. A study to determine the prevalence rate of ocular melanocytosis. Ophthalmology 1982; 89(8): 950-952.

82 Kono T, Kurome H, Shibuya Y, Hayasaka S. Ocular findings in Japanese women with nevus of Ota. Graefes Arch Clin Exp Ophthalmol 1995; 233(11): 667-671.

83 Turnbull JR, Assaf C, Zouboulis C, Tebbe B. Bilateral naevus of Ota: a rare manifestation in a Caucasian. J Eur Acad Dermatol Venereol 2004; 18(3): 353-355.

84 Ruiz-Villaverde R, Blasco Melguizo J, Buendia Eisman A, Serrano Ortega S. Bilateral Ota naevus. J Eur Acad Dermatol Venereol 2003; 17(4): 437-439.

85 Ruiz-Villaverde R, Sanchez-Cano D, Villaverde-Gutierrez C. Bilateral naevus of Ota in a pregnant White woman. Clin Exp Dermatol 2009; 34(3): 422-424.

86 Gonder JR, Shields JA, Shakin JL, Albert DM. Bilateral ocular melanocytosis with malignant melanoma of the choroid. Br J Ophthalmol 1981; 65(12): 843-845.

87 Hidano A, Kajima H, Endo Y. Bilateral nevus Ota associated with nevus Ito. A case of pigmentation on the lips. Arch Dermatol 1965; 91(4): 357-359.

88 Skalka HW. Bilateral oculodermal melanocytosis. Ann Ophthalmol 1976; 8(5): 565-567.

89 Agero ALC, Lahmar JJ, Holzborn RM, Martin LK, Freckmann ML, Murrell DF. Naevus of Ota presenting in two generations: a mother and daughter. J Eur Acad Dermatol Venereol 2009; 23(1): 102-104. 
90 Kiewe P, Maneff I. Melanose bilaterale congenitale et familiale de L'ceil et de la Face. Contribution au probleme de la consanguinite. Ann Ocul 1934; 172: 723-728.

91 Kumari R, Thappa DM. Familial nevus of Ota. Indian J Dermatol 2006; 51: 198-199.

92 Trese MT, Pettit TH, Foos RY, Hofbauer J. Familial nevus of Ota. Ann Ophthalmol 1981; 13: 855-857.

93 Gupta GP, Gangwar DN. Naevus of Ota. Br J Ophthalmol 1965; 49: 364-368.

94 Ragge NK, Acheson J, Murphree AL. Iris mammillations: significance and associations. Eye 1996; 10(Pt 1): 86-91.

95 Gunduz K, Shields CL, Shields JA, Eagle Jr RC, Singh AD Iris mammillations as the only sign of ocular melanocytosis in a child with choroidal melanoma. Arch Ophthalmol 2000; 118(5): 716-717.

96 Joondeph BC, Goldberg MF. Familial iris melanosis - a misnomer? Br J Ophthalmol 1989; 73(4): 289-293.

97 Pal E, Chaine G, Hershkovitch D, Laroche L, Dallot A, Amouroux J. [Nevus of Ota associated with chronic glaucoma]. J Fr Ophtalmol 1997; 20(10): 771-774.

98 Foulks GN, Shields MB. Glaucoma in oculodermal melanocytosis. Ann Ophthalmol 1977; 9(10): 1299-1304.

99 Kiratli H, Irkec M. Melanocytic glaucoma in a child associated with ocular melanocytosis. J Pediatr Ophthalmol Strabismus 1997; 34(6): 380-381.

100 Koca MR, Rummelt V, Fahlbusch R, Naumann GO. [Orbital, osseous, meningeal and cerebral findings in oculodermal melanocytosis (nevus of Ota). Clinicohistopathologic correlation in 2 patients]. Klin Monbl Augenheilkd 1992; 200(6): 665-670.

101 Teekhasaenee C, Ritch R, Rutnin U, Leelawongs N Glaucoma in oculodermal melanocytosis. Ophthalmology 1990; 97(5): 562-570

102 Sugar HS. Glaucoma with trabecular melanocytosis. Ann Ophthalmol 1982; 14(4): 374-375.

103 Weiss DI, Krohn DL. Benign melanocytic glaucoma complicating oculodermal melanocytosis. Ann Ophthalmol 1971; 3(9): 958-960.

104 Gold DH, Henkind P, Sturner WQ, Baden M. Oculodermal melanocytosis and retinitis pigmentosa. Am J Ophthalmol 1967; 63(2): 271-279.

105 Gewirtzman GB, Rasmussen JE. Nevus of Ota with ipsilateral congenital cataract. Arch Dermatol 1976; 112(9): 1284-1285.

106 Holtz SJ. Congenital ocular anomalies associated with Duane's syndrome: the naevus of Ota and axial anisometropia. Am J Ophthalmol 1974; 77: 729-737.

107 Shields JA, Shields CL, Eagle Jr RC, Santos C, Singh AD. Malignant melanoma arising from a large uveal melanocytoma in a patient with oculodermal melanocytosis. Arch Ophthalmol 2000; 118(7): 990-993.

108 Infante de German-Ribon R, Singh AD, Arevalo JF, Driebe $\mathrm{W}$, Eskin T. Choroidal melanoma with oculodermal melanocytosis in Hispanic patients. Am J Ophthalmol 1999; 128(2): 251-253.

109 Gunduz K, Shields JA, Shields CL, Eagle Jr RC. Choroidal melanoma in a 14-year-old patient with ocular melanocytosis. Arch Ophthalmol 1998; 116(8): 1112-1114.

110 Biswas J, Shanmugam MP, Gopal L. Malignant melanoma of the choroid in association with oculodermal melanocytosis: a case report. Indian J Ophthalmol 1995; 43(3): 140-141.
111 Oguz V, Pazarli H, Ocakoglu O, Ustundag C, Celikkol L, Oguz O. [Ocular site of pigmentation in oculodermal melanocytosis]. J Fr Ophtalmol 1995; 18(1): 40-43.

112 Bordon AF, Wray ML, Belfort R, McLean IW, Burnier M. Choroidal malignant melanoma in association with oculodermal melanocytosis in a black patient [letter]. $\mathrm{Br} \mathrm{J}$ Ophthalmol 1995; 79(2): 191-192.

113 Seregard S, Ladenvall G, Kock E. Multiple melanocytic tumours in a case of ocular melanocytosis. Acta Ophthalmol 1993; 71(4): 562-565.

114 Bercher L, Zografos L, Egger E, Chamot L, Uffer S, Gailloud C. [Ocular melanocytosis, oculodermal melanocytosis and choroid melanomas]. Klin Monbl Augenheilkd 1991; 198(5): 361-364.

115 Gonder JR, Nichol J, Augsburger JJ, Shields JA. Ocular and oculodermal melanocytosis. Can J Ophthalmol 1985; 20(5): 176-178.

116 Brini A. A case of melanosis oculi with malignant melanoma of the choroid. Int Ophthalmol 1985; 7(3-4): 169-174.

117 Velazquez N, Jones IS. Ocular and oculodermal melanocytosis associated with uveal melanoma. Ophthalmology 1983; 90(12): 1472-1476.

118 Gonder JR, Shields JA, Albert DM, Augsburger JJ, Lavin PT. Uveal malignant melanoma associated with ocular and oculodermal melanocytosis. Ophthalmology 1982; 89(8): 953-960.

119 Gonder JR, Shields JA, Albert DM. Malignant melanoma of the choroid associated with oculodermal melanocytosis. Ophthalmology 1981; 88(4): 372-376.

120 Seelenfreund MH, Freilich DB. Ocular melanocytosis and malignant melanoma. $N$ Y State J Med 1979; 79(6): 916-917.

121 Laquis SJ, Freeman JM, Fleming JC, Wilson MW, Haik BG. A rapidly growing choroidal melanoma. Am J Ophthalmol 2002; 133(4): 580-581.

122 Shields JA, Shields CL, Naseripor M, Eagle RC, Miller J. Choroidal melanoma in a black patient with oculodermal melanocytosis. Retina 2002; 22(1): 126-128.

123 Terheyden P, Rickert S, Kampgen E, Munnich S, Hofmann UB, Brocker EB et al. [Nevus of Ota and choroid melanoma]. Hautarzt 2001; 52(9): 803-806.

124 Biswas J, Krishnakumar S. Choroidal melanoma in a Black patient with oculodermal melanocytosis.[comment]. Retina 2003; 23(1): 126; author reply.

125 Lopez-Caballero C, Saornil-Alvarez MA, Blanco-Mateos G, Frutos-Baraja JM, Lopez-Lara F, Gonzalez-Sansegundo C. [Choroidal melanoma in ocular melanosis]. Arch Soc Esp Oftalmol 2003; 78(2): 99-102.

126 Malik Rahman A, Augsburger JJ, Correa ZM. Iridociliary melanoma associated with ocular melanocytosis in a 6-year-old boy. J AAPOS 2008; 12(3): 312-313.

127 Shields CL, Eagle RC, Ip MS, Marr BP, Shields JA. Two discrete uveal melanomas in a child with ocular melanocytosis. Retina 2006; 26(6): 684-687.

128 Szuscik I, Romanowska-Dixon B, Jakubowska B, Orlowska-Heitzman J. [Uveal melanoma in patients with ocular or oculodermal melanocytosis]. Klin Oczna 2008; 110(10-12): 380-383.

129 Susskind D, Rohrbach JM. [Uveal melanoma in ocular melanocytosis]. Klin Monbl Augenheilkd 2007; 224(3): 211-213.

130 Cihelkova I, Soucek P, Sach J. Uveal melanoma in congenital ocular melanocytosis mimicking malignant transformation of the optic disc melanocytoma (a controlled case). Neuroendocrinol Lett 2006; 27(6): 729-732. 
131 Unal M, Gunalp I, Deery A, Durak I, Erekul S, Bulay O. Malignant melanoma of the optic nerve head in a case of oculodermal melanocytosis. Br J Ophthalmol 1992; 76(5): 313-315.

132 Cu-Unjieng AB, Shields CL, Shields JA, Eagle Jr RC. Iris melanoma in ocular melanocytosis. Cornea 1995; 14(2): 206-209.

133 Ticho BH, Tso MO, Kishi S. Diffuse iris nevus in oculodermal melanocytosis: a light and electron microscopic study. J Pediatr Ophthalmol Strabismus 1989; 26(5): 244-250.

134 Qian Y, Zakov ZN, Schoenfield L, Singh AD. Iris melanoma arising in iris nevus in oculo(dermal) melanocytosis. Surv Ophthalmol 2008; 53(4): 411-415.

135 Yanoff M, Zimmerman LE. Histogenesis of malignant melanomas of the uvea. 3. The relationship of congenital ocular melanocytosis and neurofibromatosis in uveal melanomas. Arch Ophthalmol 1967; 77(3): 331-336.

136 Singh AD, De Potter P, Fijal BA, Shields CL, Shields JA, Elston RC. Lifetime prevalence of uveal melanoma in white patients with oculo(dermal) melanocytosis. Ophthalmology 1998; 105(1): 195-198.

137 Harrison Butler T. A case of cyst of the iris. Trans Ophthalmol Soc UK 1921; 41: 452-455.

138 Klien BA, Tanner GS. Congenital epithelial cyst of the iris stroma. Am J Ophthalmol 1963; 55: 291-295.

139 Roy FH, Hanna C. Spontaneous congenital iris cyst. Am J Ophthalmol 1971; 72(1): 97-108.

140 Shields JA. Primary cysts of the iris. Trans Am Ophthalmol Soc 1981; 79: 771-809.

141 Naumann G, Green WR. Spontaneous nonpigmented iris cysts. Arch Ophthalmol 1967; 78(4): 496-500.

142 Gogos K, Tyradellis C, Spaulding AG, Kranias G. Iris cyst simulating melanoma. J AAPOS 2004; 8(5): 502-503.

143 Hildreth T, Maino J, Hartong T. Primary and secondary iris cysts. J Am Optom Assoc 1991; 62(8): 588-592.

144 Shen CC, Netland PA, Wilson MW, Morris WR Management of congenital nonpigmented iris cyst. Ophthalmology 2006; 113(9): 1639. e1-e7.

145 Mghaieth F, Chaker N, Limeim R, El Matri L. [Cysts of the iris in an infant. 2 case reports]. Bull Soc Belge Ophtalmol 2005; 295: 23-27.

146 Chakraborty S, Chakrabarti A, Maity P, Ray B. Atypical presentation of a primary iris cyst. J Indian Med Assoc 2004; 102(1): 36-37.

147 Regis A, Roussat B, Ullern M, Dhalluin JF, Onfray B, Mattar J et al. [Intrastromal epithelial cysts of the iris: two case studies]. J Fr Opthalmol 2004; 27(4): 379-382.

148 Behrouzi Z, Khodadoust A. Epithelial iris cyst treatment with intracystic ethanol irrigation. Ophthalmology 2003; 110(8): 1601-1605.

149 Haller JA, Stark WJ, Azab A, Thomsen RW, Gottsch JD. Surgical management of anterior chamber epithelial cysts. Am J Ophthalmol 2003; 135(3): 309-313.

150 Haller JA, Stark WJ, Azab A, Thomsen RW, Gottsch JD. Surgical approaches to the management of epithelial cysts. Trans Am Ophthalmol Soc 2002; 100: 79-84.

151 Casey M, Cohen KL, Wallace DK. Recurrence of iris stromal cyst following aspiration and resection. J AAPOS 2002; 6(4): 255-256.

152 Auw-Haedrich C, Schlunck G, Witschel H. [Primary iris stromal cyst with unusual symptoms in an adult]. Klin Monbl Augenheilkd 2000; 216(6): 420-423.
153 Shields JA, Shields CL, Lois N, Mercado G. Iris cysts in children: classification, incidence, and management. The 1998 Torrence A Makley Jr Lecture. Br J Ophthalmol 1999; 83(3): 334-338.

154 Rosenthal G, Klemperer I, Zirkin H, Lifshitz T, Pe'er J. Congenital cysts of the iris stroma. Arch Ophthalmol 1998; 116(12): 1696.

155 Lois N, Shields CL, Shields JA, Mercado G, De Potter P. Primary iris stromal cysts. A report of 17 cases. Ophthalmology 1998; 105(7): 1317-1322.

156 Brent GJ, Meisler DM, Krishna R, Baerveldt G. Spontaneous collapse of primary acquired iris stromal cysts. Am J Ophthalmol 1996; 122(6): 886-887.

157 Rohrbach JM, Steuhl KP, Erb C. [Stromal iris cyst]. Klin Monbl Augenheilkd 1993; 203(2): 146-147.

158 Capo H, Palmer E, Nicholson DH. Congenital cysts of the iris stroma. Am J Ophthalmol 1993; 116(2): 228-232.

159 Brooks SE, Baerveldt G, Rao NA, Smith RE. Primary iris stromal cysts. J Pediatr Ophthalmol Strabismus 1993; 30(3): 194-198.

160 Rummelt V, Naumann GO. Block excision of congenital and infantile nonpigmented epithelial iris cysts. Report on eight infants. Ger J Ophthalmol 1992; 1(5): 361-366.

161 Yung R, Eiferman RA. Spontaneous iris stromal cyst: a case report and review of literature. Ann Ophthalmol 1992; 24(4): 139-142.

162 Paridaens AD, Deuble K, McCartney AC. Spontaneous congenital non-pigmented epithelial cysts of the iris stroma.[see comment]. $\mathrm{Br}$ I Ophthalmol 1992; 76(1): 39-42.

163 Grutzmacher RD, Lindquist TD, Chittum ME, Bunt-Milam AH, Kalina RE. Congenital iris cysts. Br J Ophthalmol 1987; 71(3): 227-234.

164 Schrems W, Tomlinson GP, Belcher 3rd CD. NeodymiumYAG laser therapy for iris cysts. Arch Ophthalmol 1986; 104(8): 1130.

165 Kliman GH, Augsburger JJ, Shields JA. Lack of association between iris colour and primary iris cysts. Am J Ophthalmol 1986; 102(1): 95-96.

166 Coburn A, Messmer EP, Boniuk M, Font RL. Spontaneous intrastromal iris cyst. A case report with immunohistochemical and ultrastructural observations. Ophthalmology 1985; 92(12): 1691-1695.

167 Waeltermann JM, Hettinger ME, Cibis GW. Congenital cysts of the iris stroma. Am J Ophthalmol 1985; 100(4): 549-554.

168 Sugar HS, Nathan LE. Congenital epithelial cysts of the iris stroma. Ann Ophthalmol 1982; 14(5): 483-485.

169 Rush JA, Weinstein GW, Meriwether WA. Spontaneous nonpigmented iris cyst. Arch Ophthalmol 1982; 100(2): 304-305.

170 Paridaens AD, Deuble K, McCartney AC. Spontaneous congenital non-pigmented epithelial cysts of the iris stroma. Br J Ophthalmol 1992; 76(1): 39-42.

171 Gupta M, Puri P, Rundle P, Rennie IG. Primary iris stromal cyst with pseudohypopyon: an atypical presentation. $\mathrm{Br} \mathrm{J}$ Ophthalmol 2001; 85(7): 887.

172 Paul TO, Spencer WH, Webster R. Congenital intrastromal epithelial cyst of the iris. Ann Ophthalmol 1994; 26(3): 94-96.

173 Layden WE, Torczynski E, Font RL. Mucogenic glaucoma and goblet cell cyst of the anterior chamber. Arch Ophthalmol 1978; 96(12): 2259-2263.

174 Mullaney J, Fitzpatrick C. Idiopathic cyst of the iris stroma. Am J Ophthalmol 1973; 76(1): 64-68. 
175 Naumann GO, Rummelt V. Block excision of cystic and diffuse epithelial ingrowth of the anterior chamber. Report on 32 consecutive patients. Arch Ophthalmol 1992; 110(2): 223-227.

176 Winthrop SR, Smith RE. Spontaneous regression of an anterior chamber cyst: a case report. Ann Ophthalmol 1981; 13(4): 431-432.

177 Sneed SR, Vine AK. Spontaneous collapse of a primary iris cyst associated with an iris nevus. Arch Ophthalmol 1991; 109(1): 21-22.

178 Hvidberg-Hansen J, Larsen FE. Congenital iris cyst. A case studied by light and electron microscopy. Acta Ophthalmol 1972; 50(4): 501-514

179 Laval J. Spontaneous cyst of the iris. Am J Ophthalmol 1947; 30: 55-57.

180 Naumann GO, Rummelt V. Congenital nonpigmented epithelial iris cyst removed by block-excision. Graefes Arch Clin Exp Ophthalmol 1990; 228(5): 392-397.

181 Shin SY, Stark WJ, Haller J, Green WR. Surgical management of recurrent iris stromal cyst. Am J Ophthalmol 2000; 130(1): 122-123.

182 Rummelt V, Rummelt C, Naumann GO. Congenital nonpigmented epithelial iris cyst after amniocentesis. Clinicopathologic report on two children.[see comment] Ophthalmology 1993; 100(5): 776-781.

183 Zimmerman MW. A case of bilateral pigmented tumours, probably cysts of the ciliary bodies. Ophthalmic Rev 1987; 19: 129-130.

184 Pagenstecher AH. Multiple Cysten an der Irishinterflache und am Corpus ciliare. Graefes Arch Clin Exp Ophthalmol 1910; 74: 270-273.

185 Davidson SI. Spontaneous cysts of the ciliary body. Br J Ophthalmol 1960; 44: 461-466.

186 Vail D, Merz EH. Embryonic intraepithelial cyst of the ciliary processes. Trans Am Ophthalmol Soc 1951; 49: 167-183.

187 Reese AB. Spontaneous cysts of the ciliary body simulating neoplasms. Trans Am Ophthalmol Soc 1949; 47: 138-146.

188 Kunimatsu S, Araie M, Ohara K, Hamada C. Ultrasound biomicroscopy of ciliary body cysts. Am J Ophthalmol 1999; 127: 48-55.

189 Lois N, Shields CL, Shields JA, Mercado G. Primary cysts of the iris pigment epithelium. Clinical features and natural course in 234 patients. Ophthalmology 1998; 105(10): 1879-1885.

190 Fine N, Pavlin CJ. Primary cysts in the iridociliary sulcus: ultrasound biomicroscopic features of 210 cases. Can J Ophthalmol 1999; 34(6): 325-329.

191 McWhae JA, Rinke M, Crichton ACS, Van Wyngaarden C. Multiple bilateral iridociliary cysts: ultrasound biomicroscopy and clinical characteristics. Can J Ophthalmol 2007; 42(2): 268-271.

192 Azuara-Blanco A, Spaeth GL, Araujo SV, Augsburger JJ Terebuh AK. Plateau iris syndrome associated with multiple ciliary body cysts. Report of three cases. Arch Ophthalmol 1996; 114(6): 666-668.

193 Baba T, Hirooka K, Takagishi M, Sato S, Shiraga F. Plateau iris syndrome associated with cysts and nocturnal elevation of intraocular pressure. Can J Ophthalmol 2008 43(6): 725.

194 Crowston JG, Medeiros FA, Mosaed S, Weinreb RN. Argon laser iridoplasty in the treatment of plateau-like iris configuration as result of numerous ciliary body cysts. Am J Ophthalmol 2005; 139(2): 381-383.
195 Le Corre A, Dot C, Feraoun M, Burelle X, Grasswill C, Perrenoud $\mathrm{F}$ et al. [Plateau iris-like configuration resulting from numerous iridociliary cysts]. J Fr Opthalmol 2009; 32(7): 501-504.

196 Tanihara H, Akita J, Honjo M, Honda Y. Angle closure caused by multiple, bilateral iridociliary cysts. Acta Ophthalmol 1997; 75(2): 216-217.

197 Vela A, Rieser JC, Campbell DG. The heredity and treatment of angle-closure glaucoma secondary to iris and ciliary body cysts. Ophthalmology 1984; 91(4): 332-337.

198 Wintersteiner H. Ueber idiopthische Pigmentzysten der iris. Klin Monbl Augenheilkd 1906; 44: 297-298.

199 Chandler PA, Braconier HE. Spontaneous intraepithelial cysts of iris and ciliary body with glaucoma. Am Ophthalmol 1958; 45: 64-74.

200 Loewenstein A, Foster J. Malignant melanoma of Linda's and spontaneous cyst of pigmented layer of iris in same sector: contribution to histogenesis of tumours. Arch Ophthalmol 1947; 37: 8-17.

201 Augsburger JJ, Affel LL, Benarosh DA. Ultrasound biomicroscopy of cystic lesions of the iris and ciliary body. Trans Am Ophthalmol Soc 1996; 94: 259-271.

202 Krohn J, Arnes J, Rodahl E. Ciliary body melanoma simulating multiple iris cysts. Arch Ophthalmol 2007; 125(3): 428-429.

203 Zhang J, Demirci H, Shields CL, Leon JA, Shields JA, Eagle Jr RC. Cavitary melanoma of ciliary body simulating a cyst. Arch Ophthalmol 2005; 123: 569-571.

204 Vogt A. Weitere Ergebnisse der Spaltlampenmikroskopie des vorderen Bulbusabschnittes VIII. Abschnitt. Über die pathologisch veränderte Iris. Albrecht Von Graefes Arch Ophthalmol 1923; 111: 91-128.

205 Abraham SV. Special reactions to the miotic, floropryl. Am J Ophthalmol 1953; 36: 1122-1123.

206 Chin NB, Gold AA, Goodwin MB. Iris cysts and miotics. Arch Ophthalmol 1964; 71: 611-616.

207 Christensen L, Swan KC, Higgins HD. The histopathology of iris pigment changes induced by miotics. Arch Ophthalmol 1956; 55: 666-671.

208 Cowan A. Congenital and familial cysts and flocculi of the iris. Am J Ophthalmol 1936; 19: 287-291.

209 Sallo FB, Hatvani I. Recurring transitory blindness caused by primary marginal pigment epithelial iris cysts. Am J Ophthalmol 2002; 133(3): 407-409.

210 Lewis AL, Merin LM. Iris flocculi and familial aortic dissection. Arch Ophthalmol 1995; 113: 1330-1331.

211 Phowthongkum P, Burapasubkajorn P, Intarabeth P, Buddhari W, Kowitoonkij W. Familial aortic dissection and congenital iris flocculi with hypertension. Ophthalmic Genet 2008; 29(3): 126-127.

212 Hashida N, Ohguro N, Morimoto Y, Oiki E, Morisaki $\mathrm{H}$, Morisaki $\mathrm{T}$ et al. Ultrastructural appearance of iris flocculi associated with a thoracic aortic aneurysm and dissections. Br J Ophthalmol 2009; 93(10): 1409-1410.

213 Guo D-C, Pannu H, Tran-Fadulu V, Papke CL, Yu RK, Avidan $\mathrm{N}$ et al. Mutations in smooth muscle alpha-actin (ACTA2) lead to thoracic aortic aneurysms and dissections. Nat Genet 2007; 39(12): 1488-1493.

214 Morisaki H, Akutsu K, Ogino H, Kondo N, Yamanaka I, Tsutsumi Yet al. Mutation of ACTA2 gene as an important cause of familial and nonfamilial nonsyndromatic thoracic aortic aneurysm and/or dissection (TAAD). Hum Mutat 2009; 30(10): 1406-1411. 
215 Ashton N. Primary tumours of the iris. Br J Ophthalmol 1964; 48: 650-668.

216 Ferry AP. Haemangiomas of the iris and ciliary body. Do they exist? A search for a histologically proved case. Int Ophthalmol Clin 1972; 12(1): 177-194.

217 Ruttum MS, Mittelman D, Singh P. Iris haemangiomas in infants with periorbital capillary haemangiomas. J Pediatr Ophthalmol Strabismus 1993; 30(5): 331-333.

218 Haik BG, Clancy P, Ellsworth RM, Perina A, Zimmerman K. Ocular manifestations in diffuse neonatal haemangiomatosis. J Pediatr Ophthalmol Strabismus 1983; 20(3): 101-105.

219 Bryce IG, Pai V, Bradbury JA. Spontaneous resolution of iris and cutaneous haemangiomata in diffuse neonatal haemangiomatosis. Eye 1999; 13: 388-390.

220 Chang CW, Rao NA, Stout JT. Histopathology of the eye in diffuse neonatal haemangiomatosis. Am J Ophthalmol 1998; 125(6): 868-870.

221 Prost M. Cavernous haemangioma of the iris. Ophthalmologica 1987; 195(4): 183-187.

222 Shields JA, Shields CL, Eagle Jr RC. Cavernous haemangioma of the iris. Arch Ophthalmol 2008; 126(11): 1602-1603.

223 Woo SJ, Kim CJ, Yu YS. Cavernous haemangioma of the iris in an infant. J AAPOS 2004; 8(5): 499-501.

224 Ebenezer GJ, Daniel E, Job CK. Cavernous haemangioma of the iris in a leprosy patient. Br J Ophthalmol 1997; 81(7): 610-612.

225 Lam S. Iris cavernous haemangioma in a patient with recurrent hyphema. J AAPOS 1993; 28(1): 36-39.

226 Thangappan A, Shields CL, Dinowitz M, Shields JA. Iris cavernous haemangioma associated with multiple cavernous haemangiomas in the kidney, brain, and skin.[see comment]. Cornea 2007; 26(4): 481-483.

227 Stur M, Strasser G. [Sectorial racemose vascular malformation of the iris]. Klin Monbl Augenheilkd 1983; 183(1): 50-52.

228 Prost M. Arteriovenous communication of the iris. $\mathrm{Br} J$ Ophthalmol 1986; 70: 856-859.

229 Shields JA, Streicher TFE, Spirkova JHJ, Stubna M, Shields CL. Arteriovenous malformation of the iris in 14 cases. Arch Ophthalmol 2006; 124(3): 370-375.

230 Lee BJ, Jeng BH, Singh AD. OCT and ultrasound biomicroscopic findings in iris arteriovenous malformation. Ophthalm Surg Lasers Imaging 2008; 39(5): 426-428.

231 Streicher T, Spirkova J, Stubna M. [Iris racemose vascular anomalies]. Cesk Slov Oftalmol 2006; 62(2): 86-93.

232 Cobb B. Vascular tufts of the pupillary margin: a preliminary report on 44 patients. Trans Ophthalmol Soc UK 1969; 88: 211-221.

233 Francis IC, Kappagoda MB. Iris microhaemangiomas. Aust J Ophthalmol 1982; 10(3): 167-171.

234 Bakke EF, Drolsum L. Iris microhaemangiomas and idiopathic juxtafoveolar retinal telangiectasis. Acta Ophthalmol Scand 2006; 84(6): 818-822.

235 Meades KV, Francis IC, Kappagoda MB, Filipic M. Light microscopic and electron microscopic histopathology of an iris microhaemangioma. Br J Ophthalmol 1986; 70(4): 290-294.

236 Bandello F, Brancato R, Lattanzio R, Maestranzi G. Laser treatment of iris vascular tufts. Ophthalmologica 1993; 206(4): 187-191.

237 Robinson AJ, Izad AA, Noel L-P. Recurrent spontaneous microhyphema from iris vascular tufts. Can J Ophthalmol 2008; 43(1): 118-119.
238 Strauss EC, Aldave AJ, Spencer WH, Branco BC, Barsness $\mathrm{DA}$, Calman AF et al. Management of prominent iris vascular tufts causing recurrent spontaneous hyphema. Cornea 2005; 24(2): 224-226.

239 Dahlmann AH, Benson MT. Spontaneous hyphema secondary to iris vascular tufts. Arch Ophthalmol 2001; 119: 1728.

240 Andersen SR, Other A. Varix of the iris. Arch Ophthalmol 1975; 93(1): 32-33.

241 Broaddus E, Lystad LD, Schonfield L, Singh AD. Iris varix: report of a case and review of iris vascular anomalies. Surv Ophthalmol 2009; 54: 118-127.

242 Shields JA, Shields CL, Pulido J, Eagle Jr RC, Nothnagel AF. Iris varix simulating an iris melanoma. Arch Ophthalmol 2000; 118(5): 707-710.

243 Ang LP, Sim DH, Chiang GS, Yong VS. Iris varix. Eye 1997; 11(Pt 5): 733-735.

244 Cobb B, Shilling JS, Chisholm IH. Vascular tufts at the pupillary margin in myotonic dystrophy. Am J Ophthalmol 1970; 69(4): 573-582.

245 Stern LZ, Cross HE, Crebo AR. Abnormal iris vasculature in myotonic dystrophy. An anterior segment angiographic study. Arch Neurol 1978; 35(4): 224-227.

246 Mason GI. Iris neovascular tufts. Relationship to rubeosis, insulin, and hypotony. Arch Ophthalmol 1979; 97(12): 2346-2352.

247 Fechner PU. Spontaneous hyphaema with abnormal iris vessels. Br J Ophthalmol 1958; 42(5): 311-313.

248 Sellman A. Hyphaema from microhaemangiomas. Acta Ophthalmol 1972; 50(1): 58-61.

249 Perry HD, Mallen FJ, Sussman W. Microhaemangiomas of the iris with spontaneous hyphaema and acute glaucoma. Br J Ophthalmol 1977; 61(2): 114-116.

250 Awan KJ. Microhyphema. Can J Ophthalmol 1977; 12(2): 153-154.

251 Blanksma LJ, Hooijmans JM. Vascular tufts of the pupillary border causing a spontaneous hyphaema. Ophthalmologica 1979; 178(6): 297-302.

252 Podolsky MM, Srinivasan BD. Spontaneous hyphema secondary to vascular tuft of pupillary margin of the iris. Arch Ophthalmol 1979; 97(2): 301-302.

253 Akram I, Reck AC, Sheldrick J. Iris microhaemangioma presenting with total hyphaema and elevated intraocular pressure. Eye 2003; 17(6): 784-785.

254 Coleman SL, Green WR, Patz A. Vascular tufts of pupillary margin of iris. Am J Ophthalmol 1977; 83(6): 881-883.

255 Puri P, Chan J. Cobb's tufts: a rare cause of spontaneous hyphaema. Int Ophthalmol 2001; 24(6): 299-300.

256 Elgohary MA, Sheldrick JH. Spontaneous hyphaema from pupillary vascular tufts in a patient with branch retinal vein occlusion. Eye 2005; 19(12): 1336-1338.

257 Spraul CW, d'Heurle D, Grossniklaus HE. Adenocarcinoma of the iris pigment epithelium. Arch Ophthalmol 1996; 114(12): 1512-1517.

258 Shields JA, Shields CL, Mercado G, Gunduz K, Eagle Jr RC. Adenoma of the iris pigment epithelium: a report of 20 cases: the 1998 Pan-American Lecture. Arch Ophthalmol 1999; 117(6): 736-741.

259 Singh AD, Rundle PA, Longstaff S, Jacques R, Rennie IG. Iris pigment epithelial adenoma: resection and repair. Eye 2006; 20(3): 385-386.

260 Rennie IG, Parsons MA, Palmer CA. Congenital adenoma of the iris and ciliary body: light and electron microscopic observations. Br J Ophthalmol 1992; 76(9): 563-566. 
261 Dinakaran S, Rundle PA, Parsons MA, Rennie IG. Adenoma of ciliary pigment epithelium: a case series. Br J Ophthalmol 2003; 87(4): 504-505.

262 Vrabec F, Soukup F. Maligant epithelioma of the pigmented epithelium of the human iris. Am J Ophthalmol 1963; 56: 403-409.

263 Nelson CC, Hertzberg BS, Klintworth GK. A histopathologic study of 716 unselected eyes in patients with cancer at the time of death. Am J Ophthalmol 1983; 95(6): 788-793.

264 Bloch RS, Gartner S. The incidence of ocular metastatic carcinoma. Arch Ophthalmol 1971; 85(6): 673-675.

265 Shields JA, Shields CL, Kiratli H, de Potter P. Metastatic tumours to the iris in 40 patients. Am J Ophthalmol 1995; 119(4): 422-430.

266 Mayama C, Ohashi M, Tomidokoro A, Kojima T. Bilateral iris metastases from prostate cancer. Jpn J Ophthalmol 2003 47(1): 69-71.

267 Wyzinski P, Rootman J, Wood W. Simultaneous bilateral iris metastases from renal cell carcinoma. Am J Ophthalmol 1981; 92(2): 206-209.

268 O'Gorman CS, Awad ZT, Given HF. Bilateral choroidal metastases as the initial presentation of breast carcinoma. Ir Med J 2001; 94(3): 85-86.

269 Woog JJ, Chess J, Albert DM, Dueker DK, Berson FG, Craft J. Metastatic carcinoma of the iris simulating iridocyclitis. Br J Ophthalmol 1984; 68(3): 167-173.

270 Freeman TR, Friedman AH. Metastatic carcinoma of the iris. Am J Ophthalmol 1975; 80(5): 947-952.

271 Lieb WE, Shields JA, Shields CL, Spaeth GL. Mucinous adenocarcinoma metastatic to the iris, ciliary body, and choroid. Br J Ophthalmol 1990; 74(6): 373-376.

272 Chua CH, Westlake W, Rich W. Iris metastasis: an unusual cause of anterior uveitis. Postgrad Med J 1996; 72(845): 176-177.

273 Michelson JB, Grossman KR, Lozier JR, Farber M, Augsburger JJ, Crawford JB. Iridocyclitis masquerade syndrome. Surv Ophthalmol 1986; 31(2): 125-130.

274 Shields CL, Manquez ME, Ehya H, Mashayekhi A, Danzig CJ, Shields JA. Fine-needle aspiration biopsy of iris tumours in 100 consecutive cases: technique and complications. Ophthalmology 2006; 113(11): 2080-2086.

275 Grossniklaus HE. Fine-needle aspiration biopsy of the iris. Arch Ophthalmol 1992; 110(7): 969-976.

276 Gupta M, Puri P, Jacques R, Rennie IG. Fine needle aspiration biopsy: an investigative tool for iris metastasis. Eye 2001; 15(Pt 4): 541-542.

277 Pe'er J, Blumenthal EZ, Frenkel S. Punch biopsy of iris lesions: a novel technique for obtaining histology samples. Br J Ophthalmol 2007; 91(5): 660-662.

278 Rodriguez-Sains RS. Ocular findings in patients with dysplastic nevus syndrome. An update. Dermatol Clin 1991; 9(4): 723-728.

279 Toth-Molnar E, Olah J, Dobozy A, Hammer H. Ocular pigmented findings in patients with dysplastic naevus syndrome. Melanoma Res 2004; 14(1): 43-47.

280 Jakobiec FA, Silbert G. Are most iris 'melanomas' really naevi? A clinicopathologic study of 189 lesions. Arch Ophthalmol 1981; 99(12): 2117-2132.

281 Harbour JW, Augsburger JJ, Eagle Jr RC. Initial management and follow-up of melanocytic iris tumours. Ophthalmology 1995; 102(12): 1987-1993.
282 Cogan DG, Reese AB. A syndrome of iris nodules, ectopic Descemet's membrane, and unilateral glaucoma. Doc Ophthalmol 1969; 26: 424-433.

283 Wilson MC, Shields MB. A comparison of the clinical variations of the iridocorneal endothelial syndrome. Arch Ophthalmol 1989; 107(10): 1465-1468.

284 Territo C, Shields CL, Shields JA, Augsburger JJ, Schroeder RP. Natural course of melanocytic tumours of the iris. Ophthalmology 1988; 95(9): 1251-1255.

285 Paridaens D, Lyons CJ, McCartney A, Hungerford JL. Familial aggressive naevi of the iris in childhood. Arch Ophthalmol 1991; 109(11): 1552-1554.

286 Carlson DW, Alward WL, Folberg R. Aggressive nevus of the iris with secondary glaucoma in a child. $A m$ Ophthalmol 1995; 119(3): 367-368.

287 Shields JA, Shields CL, Eagle Jr RC. Melanocytoma (hyperpigmented magnocellular nevus) of the uveal tract: the 34th G Victor Simpson lecture. Retina 2007; 27(6): 730-739.

288 Marquardt R. [On a benign melanocytoma of the choroid in a 12-year-old girl]. Albrecht Von Graefes Arch Clin Exp Ophthalmol 1967; 173(4): 318-322.

289 Shields JA, Font RL. Melanocytoma of the choroid clinically simulating a malignant melanoma. Arch Ophthalmol 1972; 87(4): 396-400.

290 Barker-Griffith AE, McDonald PR, Green WR. Malignant melanoma arising in a choroidal magnacellular nevus (melanocytoma). Can J Ophthalmol 1976; 11(2): 140-146.

291 Haas BD, Jakobiec FA, Iwamoto T, Cox M, Bernacki EG, Pokorny KL. Diffuse choroidal melanocytoma in a child. A lesion extending the spectrum of melanocytic hamartomas. Ophthalmology 1986; 93(12): 1632-1638.

292 Heitman KF, Kincaid MC, Steahly L. Diffuse malignant change in a ciliochoroidal melanocytoma in a patient of mixed racial background. Retina 1988; 8(1): 67-72.

293 Leidenix M, Mamalis N, Goodart R, Harrie R, Kjeldsberg C. Malignant transformation of a necrotic melanocytoma of the choroid in an amblyopic eye. Ann Ophthalmol 1994; 26(2): 42-46.

294 Lehman LJ, Hohberger GG, Buettner H, Campbell RJ. Necrotic melanocytoma of the choroid in a 2-year-old child. J Pediatr Ophthalmol Strabismus 1997; 34(1): 40-43.

295 Brownstein S, Dorey MW, Mathew B, Little JM, Lindley JI. Melanocytoma of the choroid: atypical presentation and review of the literature. Can J Ophthalmol 2002; 37(4): 247-252.

296 Lafaut BA, Mietz H, Ortmann M, Bartz-Schmidt KU. Melanocytoma of the choroid: angiographic and histopathologic findings. Ophthalmic Surg Lasers 2002; 33(2): 158-162.

297 Robertson DM, Campbell RJ, Salomao DR. Mushroomshaped choroidal melanocytoma mimicking malignant melanoma. Arch Ophthalmol 2002; 120(1): 82-85.

298 Kurli M, Finger PT, Manor T, McCormick SA, Grossniklaus HE. Finding malignant change in a necrotic choroidal melanocytoma: a clinical challenge. Br J Ophthalmol 2005; 89: 921-922.

299 Shields JA, Augsburger JJ, Bernardino Jr V, Eller AW, Kulczycki E. Melanocytoma of the ciliary body and iris. Am J Ophthalmol 1980; 89(5): 632-635.

300 Shammas HJ, Minckler DS, Hulquist R, Sherins RS. Melanocytoma of the ciliary body. Ann Ophthalmol 1981; 13(12): 1381-1383. 
301 Adenis JP, Loubet A, Leboutet MJ, Loubet R, Robin A. [Melanocytoma of the iris and ciliary body and multiple pigmented tumours ultrastructural study]. J Fr Ophtalmol 1983; 6(3): 257-265.

302 Croxatto JO, Malbran ES, Lombardi AA. Cavitary melanocytoma of the ciliary body. Ophthalmologica 1984; 189(3): 130-134.

303 Frangieh GT, el Baba F, Traboulsi EI, Green WR. Melanocytoma of the ciliary body: presentation of four cases and review of nineteen reports. Surv Ophthalmol 1985; 29(5): 328-334.

304 Stokes DW, O'Day DM, Glick AD. Melanocytoma of the ciliary body with scleral extension. Ophthalmic Surg 1993; 24(3): 200-202.

305 Rummelt V, Naumann GO, Folberg R, Weingeist TA. Surgical management of melanocytoma of the ciliary body with extrascleral extension. Am J Ophthalmol 1994; 117(2): 169-176.

306 Biswas J, D'Souza C, Shanmugam MP. Diffuse melanotic lesion of the iris as a presenting feature of ciliary body melanocytoma: report of a case and review of the literature. Surv Ophthalmol 1998; 42(4): 378-382.

307 Bhorade AM, Edward DP, Goldstein DA. Ciliary body melanocytoma with anterior segment pigment dispersion and elevated intraocular pressure. J Glaucoma 1999; 8(2): 129-133.

308 LoRusso FJ, Boniuk M, Font RL. Melanocytoma (magnocellular nevus) of the ciliary body: report of 10 cases and review of the literature. Ophthalmology 2000; 107(4): 795-800.

309 El-Harazi SM, Kellaway J, Font RL. Melanocytoma of the ciliary body diagnosed by fine-needle aspiration biopsy. Diagn Cytopathol 2000; 22(6): 394-397.

310 Muinos Diaz Y, Saornil Alvarez MA, Mendez Diaz MC, Blanco Mateos G, Becerra Aguiar E, Esteban Casado MR et al. [Symptomatic ciliary body melanocytoma: melanocytomalytic glaucoma]. Arch Soc Esp Oftalmol 2004; 79(10): 511-514.

311 Gallego Y, Mendicute J, Ruiz M, Ruiz I, Ubeda M. [Melanocytoma of the ciliary body]. Arch Soc Esp Oftalmol 2005; 80(2): 109-112.

312 Mohamed MD, Gupta M, Parsons A, Rennie IG. Ultrasound biomicroscopy in the management of melanocytoma of the ciliary body with extrascleral extension. Br J Ophthalmol 2005; 89: 14-16.

313 Zimmerman LE. Melanocytes, melanocytic naevi, and melanocytoma. Invest Ophthalmol Vis Sci 1965; 4: 11-41.

314 Shields JA, Annesley Jr WH, Spaeth GL. Necrotic melanocytoma of iris with secondary glaucoma. Am J Ophthalmol 1977; 84(6): 826-829.

315 Nakazawa M, Tamai M. Iris melanocytoma with secondary glaucoma. Am J Ophthalmol 1984; 97(6): 797-799.

316 Cialdini AP, Sahel JA, Jalkh AE, Weiter JJ, Zakka K, Albert DM. Malignant transformation of an iris melanocytoma. A case report. Graefes Arch Clin Exp Ophthalmol 1989; 227(4): 348-354.

317 Teichmann KD, Karcioglu ZA. Melanocytoma of the iris with rapidly developing secondary glaucoma. Surv Ophthalmol 1995; 40(2): 136-144.

318 Fineman MS, Eagle Jr RC, Shields JA, Shields CL, De Potter P. Melanocytomalytic glaucoma in eyes with necrotic iris melanocytoma. Ophthalmology 1998; 105(3): 492-496.

319 Kiratli H, Bilgic S, Gedik S. Late normalization of melanocytomalytic intraocular pressure elevation following excision of iris melanocytoma. Graefes Arch Clin Exp Ophthalmol 2001; 239(9): 712-715.

320 Shields JA, Eagle Jr RC, Shields CL, Nelson LB. Progressive growth of an iris melanocytoma in a child. Am J Ophthalmol 2002; 133(2): 287-289.

321 Zhao JC, Zacks DN, Gragoudas ES, Pasquale LR. Pupil sparing excision of an atypical iris melanocytoma induces remission of secondary glaucoma. Br J Ophthalmol 2004; 88(6): 842-843.

322 Demirci H, Mashayekhi A, Shields CL, Eagle Jr RC, Shields JA. Iris melanocytoma: clinical features and natural course in 47 cases. Am J Ophthalmol 2005; 139(3): 468-475.

323 Gutierrez-Ortiz C, Pareja J, Bolivar G, Cedazo MT, Busteros JI, Teus MA. Iris melanocytoma mimicking the CoganReese syndrome with monocular pigment dissemination. Eur J Ophthalmol 2006; 16(6): 873-875.

324 Sagoo MS, Shields CL, Eagle Jr RC, Materin MA, Ehya H, McQueen B et al. Brown trabeculectomy bleb from necrotic iris melanocytoma. Acta Ophthalmol Scand 2007; 85(5): 571-572.

325 Sagoo MS, Mruthyunjaya P, Cree I, Luthert PJ, Hungerford JL. Malignant transformation of iris melanocytoma to iris ring melanoma. $\mathrm{Br} J$ Ophthalmol 2007; 91(11): 1571-1572.

326 Chen M-J, Liu J-L, Li W-Y, Lee F-L, Chou C-K, Hsu W-M. Diode laser transscleral cyclophotocoagulation in the treatment of refractory glaucoma with iris melanocytoma. J Chin Med Assoc 2008; 71(10): 546-548.

327 Malandrini A, Mittica V, Tosi GM, Paradiso A, Balestrazzi A. Clinical and ultrasound biomicroscopic features in iris melanocytoma. Ophthalmic Surg Lasers Imaging 2009; 40(1): 46-49.

328 Shields JA, Sanborn GE, Augsburger JJ. The differential diagnosis of malignant melanoma of the iris. A clinical study of 200 patients. Ophthalmology 1983; 90(6): 716-720.

329 Inoue R, Saishin Y, Shima C, Yoshikawa H, Ohguro N, Tano Y. A case of iris melanocytoma transformed to malignant melanoma. Jpn J Ophthalmol 2009; 53(3): 271-273.

330 Conway RM, Chua WC, Qureshi C, Billson FA. Primary iris melanoma: diagnostic features and outcome of conservative surgical treatment. Br J Ophthalmol 2001; 85(7): 848-854.

331 Shields CL, Shields JA, Materin M, Gershenbaum E, Singh $\mathrm{AD}$, Smith A. Iris melanoma: risk factors for metastasis in 169 consecutive patients. Ophthalmology 2001; 108(1): 172-178.

332 Rones B, Zimmerman LE. The prognosis of primary tumours of the iris treated by iridectomy. Arch Ophthalmol 1958; 60(2): 193-205.

333 Demirci H, Shields CL, Shields JA, Eagle Jr RC, Honavar SG. Diffuse iris melanoma: a report of 25 cases. Ophthalmology 2002; 109(8): 1553-1560.

334 Richardson S. Diffuse malignant melanoma of iris. Report or two cases. Trans American Acad Ophthalmol Otolaryngol 1947; 45: 327-342.

335 Rones B, Zimmerman LE. The production of heterochromia and glaucoma by diffuse malignant melanoma of the iris. Trans Am Acad Ophthalmol Otolaryngol 1957; 61: 447-463.

336 Stallard HB. Surgery of malignant melanoma of the Iris. Br J Ophthalmol 1951; 35: 774-783.

337 Duke JR, Dunn SN. Primary tumours of the iris. Arch Ophthalmol 1958; 59(2): 204-214.

338 Reese AB, Cleasby GW. The treatment of iris melanoma. Trans Am Acad Ophthalmol Otolaryngol 1959; 63(3): 296-304. 
339 Ashton N. Primary tumours of the iris. Br J Ophthalmol 1964; 48: 650-668.

340 Heath P. Tumours of the iris: classification and clinical follow-up. Trans Am Ophthalmol Soc 1964; 62: 51-85.

341 Makley Jr TA. Management of melanomas of the anterior segment. Surv Ophthalmol 1974; 19(3): 135-153.

342 Arentsen JJ, Green WR. Melanoma of the iris: report of 72 cases treated surgically. Ophthalmic Surg 1975; 6(2): 23-37.

343 Sunba MS, Rahi AH, Morgan G. Tumours of the anterior uvea. I. Metastasizing malignant melanoma of the iris. Arch Ophthalmol 1980; 98(1): 82-85.

344 Stallard HB. Surgery of malignant melanoma of the iris. $\mathrm{Br}$ J Ophthalmol 1951; 35(12): 774-783.

345 Batioglu F, Gunalp I. Malignant melanomas of the iris. Jpn J Ophthalmol 1998; 42(4): 281-285.

346 Shields CL, Naseripour M, Shields JA, Freire J, Cater J. Custom-designed plaque radiotherapy for nonresectable iris melanoma in 38 patients: tumour control and ocular complications. Am J Ophthalmol 2003; 135(5): 648-656.

347 Bianciotto C, Shields CL, Kang B, Shields JA. Treatment of iris melanoma and secondary neovascular glaucoma using bevacizumab and plaque radiotherapy. Arch Ophthalmol 2008; 126(4): 578-579.

348 Damato B, Kacperek A, Chopra M, Sheen MA, Campbell IR, Errington RD. Proton beam radiotherapy of iris melanoma. Int J Radiat Oncol Biol Physics 2005; 63(1): 109-115.

349 Lumbroso-Le Rouic L, Delacroix S, Dendale R, LevyGabriel C, Feuvret L, Noel G et al. Proton beam therapy for iris melanomas. Eye 2006; 20(11): 1300-1305.

350 Rundle P, Singh AD, Rennie I. Proton beam therapy for iris melanoma: a review of 15 cases. Eye 2007; 21(1): 79-82.

351 Diener-West M, Hawkins BS, Markowitz JA, Schachat AP. A review of mortality from choroidal melanoma. II. A meta-analysis of 5-year mortality rates following enucleation, 1966 through 1988. Arch Ophthalmol 1992; 110(2): 245-250.

352 Kujala E, Makitie T, Kivela T. Very long-term prognosis of patients with malignant uveal melanoma. Invest Ophthalmol Vis Sci 2003; 44(11): 4651-4659.

353 Davidorf FH. The melanoma controversy. A comparison of choroidal, cutaneous, and iris melanomas. Surv Ophthalmol 1981; 25(6): 373-377.
354 Prescher G, Bornfeld N, Becher R. Nonrandom chromosomal abnormalities in primary uveal melanoma. J Natl Cancer Inst 1990; 82(22): 1765-1769.

355 Sisley K, Rennie IG, Cottam DW, Potter AM, Potter CW, Rees RC. Cytogenetic findings in six posterior uveal melanomas: involvement of chromosomes 3, 6, and 8 . Genes Chromosomes Cancer 1990; 2(3): 205-209.

356 Prescher G, Bornfeld N, Horsthemke B, Becher R. Chromosomal aberrations defining uveal melanoma of poor prognosis [letter]. Lancet 1992; 339(8794): 691-692.

357 Prescher G, Bornfeld N, Hirche H, Horsthemke B, Jockel KH, Becher R. Prognostic implications of monosomy 3 in uveal melanoma. Lancet 1996; 347(9010): $1222-1225$

358 Sisley K, Rennie IG, Parsons MA, Jacques R, Hammond DW, Bell SM et al. Abnormalities of chromosomes 3 and 8 in posterior uveal melanoma correlate with prognosis. Genes Chromosomes Cancer 1997; 19(1): 22-28.

359 Damato B, Duke C, Coupland SE, Hiscott P, Smith PA, Campbell I et al. Cytogenetics of uveal melanoma: a 7-year clinical experience. Ophthalmology 2007; 114(10): 1925-1931.

360 White VA, Horsman DE, Rootman J. Cytogenetic characterization of an iris melanoma. Cancer Genet Cytogenet 1995; 82(1): 85-87.

361 Sisley K, Brand C, Parsons MA, Maltby E, Rees RC, Rennie IG. Cytogenetics of iris melanomas: disparity with other uveal tract melanomas. Cancer Genet Cytogenet 1998; 101(2): 128-133.

362 Grossniklaus HE, Wilson MW, Barron BC, Lynn MJ. Anterior $v s$ posterior intraocular melanoma. Metastatic differences in a murine model. Arch Ophthalmol 1996; 114(9): 1116-1120.

363 Canovas D, Rennie IG, Nichols CE, Sisley K. Local environmental influences on uveal melanoma: vitreous humor promotes uveal melanoma invasion, whereas the aqueous can be inhibitory. Cancer 2008; 112(8): 1787-1794

364 Mudhar HS, Saunders E, Rundle P, Rennie IG, Sisley K. The in vivo modulatory effects of an anterior-chamber microenvironment on uveal melanoma. Br J Ophthalmol 2009; 93(4): 535-540. 